NBER WORKING PAPER SERIES

\author{
NON-KEYNESIAN EFFECTS OF FISCAL \\ POLICY CHANGES: INTERNATIONAL \\ EVIDENCE AND THE SWEDISH EXPERIENCE
}

Francesco Giavazzi

Marco Pagano

Working Paper 5332

\author{
NATIONAL BUREAU OF ECONOMIC RESEARCH \\ 1050 Massachusetts Avenue \\ Cambridge, MA 02138 \\ November 1995
}

Forthcoming in the Swedish Economic Policy Review, May 1996. A preliminary version of this paper was presented at the conference "Growing Government Debt: International Experiences," Stockholm, 12 June 1995. We thank Tito Boeri, Ingemar Hansson, Giuseppe Nicoletti and Bharat Barot for providing data, and Jonas Agell, Olivier Blanchard, Francesco Corielli, Carlo Favero, Niels Gottfries, Tullio Jappelli and Pierpaolo Benigno for useful discussions and suggestions. Ettore Damiano, Davide Lombardo and Giovanni Radicella have provided outstanding research assistance. This paper is part of NBER's research program in International Finance and Macroeconomics. Any opinions expressed are those of the authors and not those of the National Bureau of Economic Research.

() 1995 by Francesco Giavazzi and Marco Pagano. All rights reserved. Short sections of text, not to exceed two paragraphs, may be quoted without explicit permission provided that full credit, including () notice, is given to the source. 


\title{
NON-KEYNESIAN EFFECTS OF FISCAL \\ POLICY CHANGES: INTERNATIONAL EVIDENCE AND THE SWEDISH EXPERIENCE
}

\begin{abstract}
In earlier work we documented two episodes in which a sharp fiscal consolidation was associated with a surprisingly large expansion in private domestic demand. In this paper we draw on further evidence to investigate if and when fiscal policy changes can have such non-Keynesian effects. In the first part of the paper, we analyze cross-country data for 19 OECD countries. In the second part, we concentrate on the Swedish fiscal expansion of the early 1990s. The crosscountry evidence on private consumption confirms that fiscal policy changes - both contractions and expansions - can have non-Keynesian effects if they are sufficiently large and persistent. It also suggests that these effects can result not only from changes in public consumption, but to some extent also from changes in taxes and transfers. The latter result is also consistent with the Swedish experience, where a decrease in net taxes (with almost no change in public consumption) was associated with a dramatic fall in private domestic demand. Our evidence and that from other studies agree that during the Swedish fiscal expansion of the early 1990s a large negative error appears in the consumption function. There is less consensus about how this error should be interpreted, but it is clear that the most obvious candidates (wealth effects and after-tax real interest rate effects) are not sufficient to explain it. This error may reflect a large downward revision of permanent disposable income, which affected the consumption of Swedish households over and beyond the negative effects of the drop in real asset prices. We suggest that this revision in permanent income may have been triggered, at least partly, by the fiscal expansion of the early 1990 s.
\end{abstract}

Francesco Giavazzi

via Bigli, 21

20136 Milano

ITALY

and NBER
Marco Pagano

via Catullo, 64

80122 Napoli

ITALY 
"In Italy some fear the recessionary effects of further budget cuts. They should not: Italy belongs to that - fortunately small - group of countries where the public debt-GDP ratio is so high that budget cuts have expansionary, rather than depressing, effects on economic activity" (Massimo Russo, Head of IMF European Dept., talking at a conference in Rome, 6 June 1995)

Most fiscal consolidation plans aim at stabilizing and possibly reducing the public debt-GDP ratio. Not all such plans succeed. Sometimes the fiscal stabilization induces a recession. The fall in income works against the stabilization of the debt-GDP ratio in two ways: directly, by reducing the denominator of the ratio (or its growth rate); indirectly, by triggering the automatic fiscal stabilizers, and thus adding to public debt. The Irish experience of 1982-84 is a good example: the full-employment primary deficit was cut by more than 7 percent of GDP, but far from falling, the debt-GDP ratio increased by 6.8 percent, largely because the attempted stabilization was accompanied by an unprecedented fall in private consumption.

In some cases, however, the reverse occurs: a drastic fiscal stabilization is accompanied by a vigorous economic expansion, which helps in compressing the debt-GDP ratio. The Danish fiscal stabilization of 1983-86 and the second Irish stabilization of 1987-89 stopped the growth of the debt-GDP ratio largely because they were accompanied by an above-trend increase in GDP. As documented in Giavazzi and Pagano (1990), in both cases private consumption and investment grew vigorously despite a reduction in the full-employment budget deficit of $\mathbf{7 . 2}$ percent of GDP in Denmark, and 5.7 percent in Ireland. In Denmark the fiscal consolidation was achieved by stabilizing real government consumption, cutting public investment and raising net taxes. In Ireland, it was done almost single-handedly by slashing government consumption and investment: the increase in net taxes was mainly due to the output expansion, rather than to structural changes in the tax system. 
These examples show that the recipe for a successful stabilization crucially depends on its effects on private demand. Thus, from the point of view of policy makers it becomes essential to identify:

(i) the characteristics of a consolidation plan that make a positive response of private demand more likely. Must changes in fiscal variables be large and persistent in order to produce non-Keynesian effects? Are these effects more likely to arise from public consumption cuts, from tax increases or from reductions of public transfers?

(ii) the circumstances in which a consolidation plan is most likely to result in a private demand expansion. For example, is this outcome more likely if the consolidation takes place in a country whose debt-GDP ratio is very high (as stated in the opening quote of this paper) or has been rising steeply in the recent past?

In this paper we try to make some headway on the first of these two policy questions (leaving the second to further research). After a bird's eye review of what theory has to say on these issues (section 1), we produce evidence from 19 OECD countries from 1970 to 1994 (section 2). A cursory look at the data suggests that changes in the primary deficit, and particularly in government consumption, have non-monotonic effects on private demand. Cuts in government consumption and in the primary deficit of "normal" dimensions tend to be associated with a contraction of private demand, but when the change in government consumption or in the deficit becomes very large and/or persistent, its correlation with private demand switches sign: a severe contraction tends to be associated with an increase in private demand, while abnormal budget expansions are correlated with private demand contractions. To go beyond this purely descriptive level and control for the many other variables that may affect private demand, we turn to panel regressions on our sample of countries, focusing on the behavior of private consumption. The results broadly confirm that the effects of changes in 
taxes, in transfers and in government consumption are non-monotonic, and suggest that the switch in sign is related to the magnitude of the fiscal action and to its persistence.

Our panel data contain information about a large set of countries, but they lack the detailed statistical information typically available in national sources, such as data on wealth and its components, asset prices, etc. To exploit such detailed statistical information one must focus on the experience of specific countries. In Giavazzi and Pagano (1990) we analyzed the experience of Denmark and Ireland. In section 3 of this paper we focus on Sweden, and in particular on the budget expansion that occurred between 1990 to 1993 - an episode in which, according to our cross-country evidence, fiscal policy changes may have produced nonKeynesian effects. The special interest of this episode lies in the fact that $(i)$ it consisted of a conspicuous budget expansion, rather than a budget cut as in the Danish and Irish episodes of the 1980s, and (ii) it resulted from tax cuts and increases in transfers, with almost no change in the ratio of public consumption to potential GDP. It thus allows us to investigate how private spending reacts to large changes in the government's financial policies, for an almost invariant path of public consumption. 


\section{Non-Keynesian effects of fiscal policy: a birds' eye view of the theories}

Spending cuts or tax increases can produce an increase in private consumption only if they raise the market value of non-human wealth or the households' perception of their permanent income. Wealth effects are triggered by changes in interest rates. A reduction in the deficit can reduce interest rates either via a traditional crowding-in mechanism or by reducing the default premium on public debt - if former policies were perceived as unsustainable and the fiscal correction restores government solvency.

Changes in permanent income depend on expectations. A spending cut that is sufficiently large and (believed to be) persistent can signal a future reduction in the tax burden, and therefore an increase in permanent disposable income, as pointed out by Feldstein (1982) and Drazen (1990). But even small spending cuts can produce a large increase in private consumption. For example, this occurs if a regime change is expected when government consumption has reached an "excessive" level. Bertola and Drazen (1993) have elegantly illustrated this point in a model where public consumption follows a random walk with drift until its ratio to output reaches an unobserved critical point -- at which it may jump down discontinuously.

Conversely, a tax cut can paradoxically lower permanent income and thus private consumption. Sutherland (1995) shows that this can happen in an economy where consumers have finite horizons if the debt-income ratio is already very high. In this situation a tax cut that

leads to a further increase in public debt may induce consumers to believe that the "day of reckoning" has come closer, so that more taxes will fall on them rather than on the next generation. A related point had been made by Blanchard (1990). In his model if the government cuts taxes today, it will have to raise them even further tomorrow, because of the 
accrued interest payments. If the deadweight cost of taxes is an increasing function of the tax rate, this intertemporal shift in taxes translates into a larger discounted deadweight loss - and thus in a reduction in permanent income and consumption. This line of reasoning can be extended to deal with other non-linear effects of fiscal policy. For instance, assume that the current policies are unsustainable, so that unless they are abandoned within a certain time frame they will lead to the repudiation of public debt, with great disruptions to the real economy. Cutting taxes increases the probability of default, thus reducing the present discounted value of the future income of the private sector.

Similar arguments suggest that the response of private investment to fiscal policy may be non-monotonic. As in the case of consumption, this may occur either through the channel of interest rates, or via expectations of future after-tax cash-flows.

The theories briefly mentioned in this section have a number of testable predictions. Some relate to the size and persistence of the fiscal correction, others to the level of the ratio of government consumption to GDP or public debt to GDP at the time of the correction. In this paper we investigate if the sign of the response of private demand to fiscal policy actions depends on their size and persistence. 


\section{Fiscal policy changes and private demand in the OECD countries: $1976-92$}

In this section we investigate under what conditions a fiscal consolidation can lead to an increase in private demand - and in particular in private consumption - and, viceversa, a loosening of fiscal policy can lead to a fall in private demand.

As mentioned in the previous section, the circumstances in which such non-Keynesian effects might emerge have to do with the timing of the fiscal action, with its magnitude and with the particular mix of spending and tax changes chosen by the government. They may be expected particularly when the fiscal action occurs against the backdrop of a high or rapidly rising ratio of debt to income or of public consumption to income, and when the size of the discretionary fiscal correction is particularly large and persistent. In this paper we concentrate only on the last of these factors - the size and persistence of discretionary fiscal actions. We leave to future research the analysis of the other factors - the level reached by public debt and by public consumption relative to GDP.

Our empirical analysis uses yearly data for 19 OECD countries from the early 1970 s to 1992 on the following variables: income, private consumption, business investment, taxes, transfers, public debt and government consumption. For income, taxes and transfers we also use the OECD cyclically-adjusted series. ${ }^{1}$

\footnotetext{
1The countries are: Austria, Australia, Belgium, Canada, Denmark, Finland, France, Germany, Greece, Ireland, Italy, Japan, Netherlands, Norway, Portugal, Spain, Sweden, U.K., U.S.A.. For some of them (e.g. Germany) the data start in the mid-1960s. For others they are not available before the mid-seventies. The complete data set starts in 1978 . Variables and sources are as follows. Consumption: total private consumption expenditure. Income: national disposable income, defined as GDP at market prices plus net international transactions which include indirect taxes, production subsidies, labor and capital income, liability insurance premia and unilateral transfers. Income data are drawn from OECD - National Accounts (hereafter $N A$ ). Private consumption: total private final consumption expenditure, drawn from $N A$ for all countries except Austria, Greece, Ireland, Portugal and Spain, for which data are drawn from $I M F$ - International Financial Statistics (hereafter IFS). Business investment: same sources as for private consumption. Taxes: sum of household taxes, business taxes, indirect taxes and other revenues, all provided directly by the OECD. Transfers: sum of transfers plus subsidies, drawn from $N A$. Government consumption: same sources as for private consumtion. All variables are deflated by the consumer price index (drawn from European Economy
} 


\subsection{A first look at the data.}

Figure 1 offers a first look at the data. On the horizontal axis we measure the change in the cyclically-adjusted budget balance net of interest, expressed as a percent of potential GDP. This is plotted against the change in total private consumption, also measured as a percentage of potential GDP. Each point in the diagram corresponds to a fiscal policy "episode", defined as a period in which the structural component of the primary fiscal balance changed in the same direction without interruptions. So an episode consists of a single observation if the change in the cyclically-adjusted primary deficit lasts for one year only; if instead the fiscal impulse keeps the same sign for several consecutive years, the observation cumulates the change in the fiscal variables and in private consumption. We do this in order to capture some of the time series information present in the data, and especially the persistent or transient nature of fiscal corrections. There is a total of 223 episodes in the sample.

To summarize the correlation present in the data, we divide the horizontal axis in bands and then connect the cross-median points of each band with a cubic spline. This nonparametric technique has the advantage of being more robust to the presence of outliers than the OLS regression of a polynomial function, even though it is sensitive to the chosen number of bands. ${ }^{2}$ But the resulting curve is qualitatively very similar to that obtained by fitting a regression of the change in consumption on a third-degree polynomial of the fiscal variable

for EU countries, USA and Japan, and from IFS for the other countries) and divided by population (data drawn from IFS). The cyclically corrected series for income, total government consumption and for each component of taxes and subsidies were provided directly by the OECD.

${ }^{2}$ The higher the number of bands, the lower the amount of smoothing in the connecting line. Considering the large amount of noise present in this bivariate representation of the data, we have kept the number of bands relatively low in all the figures (8 bands in Figure 1, 2, and 4, and 7 bands in Figure 3). The noise clouding the relationships in the figures is partly due to the fact that private demand obviously depends on many other factors beside fiscal variables. 
(the coefficients on the non-linear terms of this regression are statistically significant, confirming the non-monotonicity of the relationship).

For cumulative changes in the cyclically-adjusted primary deficit roughly within \pm 5 percent of potential output, the relationship appears to be positively sloped: in this "normal range" a fiscal expansion is associated with an increase in private consumption, and viceversa a fiscal contraction is associated with a reduction in private consumption, as one would expect from a Keynesian textbook. Outside this range, however, the relationship becomes negative: a discretionary fiscal expansion in excess of 5 percent of potential output leads to a fall in private consumption, and viceversa. This negative correlation is more evident for large fiscal contractions than for large fiscal expansions, where it is essentially driven by the Swedish episode of 1990-93. Figure 2 repeats the exercise replacing private consumption with private domestic demand, i.e. consumption plus investment (as a percent of potential GDP). The nonlinear pattern is similar to that observed in the previous figure.

In the figures, the codes identify the episodes that fall outside the normal range of fiscal policy changes. ${ }^{3}$ These episodes include the Danish and Irish stabilizations analyzed in Giavazzi and Pagano (1990) and the Swedish fiscal expansion of 1990-93 to be analyzed in detail later in this paper. But the figures also indicate other instances of "expansionary budget cuts" (Greece in 1990-94 and Sweden in 1986-87) and of "contractionary budget expansions" (Finland in 1977-80 and 1990-92, Sweden in 1977-79, Japan in 1990-94, Australia in 199094). This suggests that the Danish and Irish stabilizations of the 1980s may not be isolated cases, but rather conspicuous instances of a macroeconomic regularity.

\footnotetext{
${ }^{3}$ The first part of the code corresponds to the name of the country (aul = Australia, bel $=$ Belgium, can = Canada, $\mathrm{dk}=$ Denmark, $\mathrm{fr}=$ France, fin $=$ Finland, ger $=$ Germany, gre $=$ Greece, ir $=$ Ireland, it $=$ Italy, jap $=$ Japan, net $=$ Netherlands, nor $=$ Norway, por $=$ Portugal, swe $=$ Sweden, $u k=$ United Kingdom). The second part of the code indicates the period of the corresponding fiscal episode.
} 
Figures 3 and 4 measure the fiscal stance via the change in government consumption (as a fraction of potential GDP) rather than by the change in the structural deficit. As in the first two figures, the relationship appears to be non-monotonic: it is increasing for cumulative changes in government consumption within the \pm 2 percent range, and decreasing outside this range. But in this case, more evidently than for changes in the deficit, the non-Keynesian result also appears asymmetric: while present for large cuts in spending, it is hardly detectable for large increases in spending.

Admittedly, the evidence summarized in these figures is purely suggestive, and far from conclusive. There is much unexplained variation in the data, witness to the fact that changes in private consumption and investment also depend on factors other than fiscal policy changes, such as the state of international demand. For instance, Figure 2 reveals that most of the budget expansions associated with a fall in private demand happened in the early 1990s, a period of worldwide recession. So one may suspect that the observations which could be classified as instances of a non-Keynesian regime actually reflect a spurious correlation between fiscal variables and private demand, arising from the effects of other exogenous variables. We must check what happens to the correlation between fiscal impulses and private demand when we control for these other factors via regression analysis.

\subsection{Cross-country regressions}


In this section we present the results from time series regressions for private consumption on a cross-section of countries. Compared to studies of individual countries, this exercise has an advantage and a weakness. The advantage is that we can pool information for a large number of countries. The cost arises from the lack of international comparable data on a number of important variables. First, our data do not distinguish between consumption of durables and non-durables, which forces us to neglect the differences in households' demand between durables and non-durables. Second, we cannot use household labor income and wealth at market value among the regressors. For most countries in our sample these variables are not available; where they are available, they seldom are internationally comparable. As a result, our regressors only include national income, fiscal variables and world income (defined as the aggregate national income of all the countries in our sample). All series are deflated by the consumer price index, divided by the population and transformed into logarithms. ${ }^{4}$

\subsubsection{Model specification}

We specify our consumption function as follows:

$$
\begin{aligned}
\Delta c_{t}= & \alpha_{0}+\alpha_{1} c_{t-1}+\alpha_{2} \Delta y_{t}+\alpha_{3} y_{t-1}+x_{t} \beta \\
& +\left(1-d_{t}\right) \cdot\left(\Delta z_{t}, z_{t-1}\right) \cdot \gamma+d_{t} \cdot\left(\Delta z_{t}, z_{t-1}\right) \cdot \delta+\varepsilon_{t},
\end{aligned}
$$

where $c$ and $y$ denote consumption and income, $x$ is a vector of country dummies and of variables intended to capture worldwide shocks, $z$ is a vector of fiscal variables (taxes,

${ }^{4}$ For data definitions and sources, see footnote 2. 
transfers and government consumption), and $d$ is a dummy which equals 1 during episodes of protracted and sizable budget cuts or expansions, or of fiscal actions that are very drastic, even if not persistent. This dummy tries capture the points of figure 1 where the change in the cyclically-adjusted primary deficit is abnormally large as a percentage of potential GDP. More precisely, for a given country at time $t$ this dummy equals 1 if the cumulative change in the structural deficit:

(i) in 4 successive years including $t$ exceeds 3 percent of potential GDP, or

(ii) in 3 successive years including $t$ exceeds 3 percent of potential GDP, or

(iii) in 2 successive years including $t$ exceeds 2 percent of potential GDP, or

(iv) if the change in the structural deficit in year $t$ exceeds 3 percent, and equals 0 otherwise.

Writing out the fiscal variables in the vector $z$, the consumption function (1) becomes:

$$
\begin{aligned}
\Delta c_{t} & =\alpha_{0}+\alpha_{1} c_{t-1}+\alpha_{2} \Delta y_{t}+\alpha_{3} y_{t-1}+x_{t} \beta_{t}+ \\
& +\left(\gamma_{1} \Delta \tau_{t}+\gamma_{2} \tau_{t-1}+\gamma_{3} \Delta t r_{t}+\gamma_{4} t r_{t-1}+\gamma_{5} \Delta g_{t}+\gamma_{6} g_{t-1}\right) \cdot\left(1-d_{t}\right) \\
& +\left(\delta_{1} \Delta \tau_{t}+\delta_{2} \tau_{t-1}+\delta_{3} \Delta t r_{t}+\delta_{4} t r_{t-1}+\delta_{5} \Delta g_{t}+\delta_{6} g_{t-1}\right) \cdot d_{t}+\varepsilon_{t}
\end{aligned}
$$

where $\tau$ denotes taxes, $t r$ transfers and $g$ government consumption.

Our specification tries to attain three objectives. First, it aims to nest the Keynesian view where consumption is driven by national income mimus net taxes and the neoclassical model where taxes are irrelevant and private consumption depends on national income mimus government consumption. This explains why taxes, transfers and public consumption are included as separate regressors. 
Second, we want to allow for the fact that fiscal variables may have different effects on consumption depending on the size and duration of the fiscal impulse. This is done by interacting fiscal variables with the $d$ dummy, which identifies periods of sharp and/or persistent discretionary changes in the budget. As mentioned in the introduction, the idea is that a large and persistent cut in public consumption may induce households to believe that tax pressure will be permanently lower, thus raising permanent income and consumption; in contrast, a small and temporary spending cut may leave their consumption choices unaffected. Similarly, a small increase in taxes would normally dampen private consumption or at best leave it unaffected, but a large increase in taxes may paradoxically lead to an increase in consumption. This is because sharp budgetary corrections often occur in periods of severe fiscal crisis, when a failure to cut the budget may lead to a "financial meltdown", with severe output losses. In such situations, a large increase in taxes or reduction in transfers may reduce the chances of the financial crisis, and of the associated output losses, and thus encourage private consumption.

Thirdly, the specification of equation (1') is intended to capture both the short-run dynamics and the long-run properties of the relationship between consumption, income and the fiscal variables. The coefficient $\alpha_{2}$ is the short-run elasticity and $\alpha_{3} / \alpha_{1}$ is the long-run elasticity of consumption to income. The latter is expected to be close to 1 , reflecting the remarkable stability of the consumption-income ratio in most countries. The coefficients $\beta_{1}$ and $\beta_{2} / \alpha_{1}$ are the short- and long-run elasticities of consumption to taxes in "normal times", while $\gamma_{1}$ and $\gamma_{2} / \alpha_{1}$ are their counterparts in periods of sharp and/or persistent fiscal action. The other coefficients have a similar interpretation. As noted by Blinder and Deaton (1986), this flexible distributed lag model "accommodates, or 'nests', many of the specifications that have been discussed in the literature - including both 'Euler-type' specifications and the error- 
correction model that has been much recommended by David Hendry and several collaborators in the United Kingdom" (p. 474).

\subsubsection{Estimation method and results}

Equation (1') is estimated with three alternative estimation methods. The results of ordinary least squares (OLS) and robust estimation are displayed in Panel A of Table 1, and the twostage least square (2SLS) estimates are reported in Panel B of the same table. All the regressions include country dummies, but two alternative sets of variables to proxy for worldwide shocks. These are meant to capture international factors affecting national consumption over and above those reflected in national income, such as the oil shocks of the seventies and the countershock of 1986; the stock market boom of the mid-eighties and the 1987 crash; the common world trends in real interest rates, etc. We proxy these common factors by including in the list of regressors either $(i)$ the growth rate of world income (net of the home country's income) and its lagged level, or (ii) calendar year dummies. Each regression is estimated with both specifications.

Columns (1) and (2) display the OLS estimates of these two specifications. In both of them, the long-run elasticity of consumption to income is not significantly different from 1 . The world income variables enter with significant coefficients in column 1. Similarly, the calendar year dummies are jointly significant in column 2 (world income is not significant if entered in the regression together with the year dummies).

More importantly, the coefficients of the fiscal variables indicate that private consumption reacts quite differently to fiscal policy depending on the magnitude and persistence of the policy 
action. In "normal times" $(d=0)$, the coefficients of lagged taxes and transfers are precisely estimated, and their signs indicate that the long-run elasticities of consumption with respect to taxes and transfers conform to the predictions of the Keynesian model. The coefficients of government consumption suggest that it stimulates private consumption in the short (but not in the long) run.

However, all these coefficients switch sign when estimated outside "normal times", i.e. when changes in the cyclically-adjusted deficit are particularly large and/or persistent $(d=1)$. In this regime, the coefficients of the lagged variables are estimated precisely and indicate that higher taxes and lower transfers increase private consumption: a 1 dollar increase in taxes is estimated to raise consumption by $15-20$ cents in the long-run, and a 1 dollar cut in transfers has approximately the same effect. Higher public consumption has a negative effect on private consumption, although here only the impact coefficient is precisely estimated: 1 extra dollar of public consumption reduces private consumption by 10 cents in the short run.

Even though the year and country dummies should partly control for the influence of outliers in the OLS regressions, we re-estimate both regressions with a method that reduces the weight assigned to outliers - the Huber robust estimator - in order to reduce the probability that our results are only driven by few episodes. The results, displayed in columns 3 and 4, confirm the findings for government consumption in both regimes. As for taxes and transfers, on the whole the sign of their effects tends to agree with the OLS estimates but their coefficients are estimated less precisely.

The two regressions are also re-estimated with 2SLS, to take into account the endo- geneity of current income and of the fiscal variables. The results are reported in Panel B of Table 1. Columns 1 and 2 show the estimates for the specification which includes world income among the regressors. The difference between the estimates in the two columns only lies in the list of 
instruments. In column 1, the instruments include the lagged values of income, consumption and of the fiscal variables; country and time dummies; and the current change and lagged level of world income. In column 2, the last two instruments are interacted with country dummies, so that world income can affect differently each country's endogenous variables (income, taxes, public spending, etc.) in the first-stage regressions.

This apparently small change in the list of instruments makes a substantial difference for the precision of the estimated coefficients of lagged consumption, of the income variables and of the fiscal variables. In column 1 most of the coefficients of the fiscal variables are not significant at conventional levels, especially in the "normal" fiscal regime. In column 2, instead, transfers enter the regression with significant positive coefficients in "normal times", while taxes and government consumption have significant coefficients (respectively positive and negative) outside "normal times". So the pattern becomes similar to that of the OLS regressions. We attribute the difference between the estimates in these two columns to the fact that in column 1 the first-stage regressions are highly constrained: they effectively impose a common dynamic structure on the processes which generate income, taxes, transfers and public spending across all the countries. As a result, the instrumented variables lose much of their informational content in the second-stage regressions. This problem is largely overcome even by allowing just world income to enter with country-specific coefficients in the first-stage regressions.

In column 3 the regression is re-estimated replacing the world income variables with country dummies in the list of regressors but keeping the list of instruments unchanged relative to column 2. The results are similar, except that now the coefficients of transfers are no longer significant in "normal times" while the coefficient on lagged transfers is negative and significant outside "normal times". For the latter regime, the pattern of results is similar to that of the OLS regressions: taxes and transfers appear to have non-Keynesian effects on private consumption in 
the long run, and government consumption has a negative effect on private consumption even in the short run.

Finally, in columns 4 and 5 we replicate the last two regressions imposing no cross-country constraints in the first-stage regressions (all the instruments are interacted with country dummies). The general pattern of the results is now very close to those obtained with the OLS regressions: there is a definite switch in the sign of the coefficients of the fiscal variables across the two regimes.

In conclusion, regression analysis appears to confirm the non-monotonic relationship between private consumption and fiscal variables detected in figures 1 and 3 . The result that sharp and/or persistent fiscal impulses are likely to have non-Keynesian effects appears to be fairly robust to the presence of outliers and the endogeneity of income and of the fiscal variables. These non-Keynesian effects are not only associated to changes in government consumption, but to some extent also to changes in taxes and transfers. This is a novelty relative to our earlier study (Giavazzi and Pagano, 1990), where only changes in government consumption were recognized as a potential source of non-Keynesian effects. Moreover, this finding parallels that by Alesina and Perotti (1995), who report that budget cuts implemented by slashing transfers or public sector wages are more likely to be "successful" at stabilizing the debt-GDP ratio than those obtained without reducing transfers and wages. Our results suggest that this may arise via the "non-Keynesian" effect that cuts in transfers have on private consumption.

In this section we have confined our analysis to one of the predictions of the theories mentioned in the introduction - that sharp and persistent fiscal actions have non-standard effects on private consumption. Several other predictions await testing. For instance, in Bertola and Drazen (1993) even a small cut in public consumption can have powerful positive 
effects on private consumption if the ratio of public consumption to GDP is "critically" high. And in Blanchard (1990) the effect of changes in net taxes switches sign depending on the level of the debt-income ratio. Future research will have to investigate if non-Keynesian effects may be associated not only with the type of fiscal actions (their size and persistence), but also with the situation in which they are carried out (such as the level reached by public debt, by public consumption or by the default premium on public debt). 


\section{The Swedish experience after 1989: a contractionary fiscal expansion?}

The regression results reported in the previous section still suffer from an important shortcoming: our explanatory variables do not comprise a measure of household wealth, whose value can vary considerably at times of unusually large fiscal impulses, as we found in our former study on the Danish and Irish stabilizations of the 1980s. Neglecting wealth effects implies that we cannot tell if the non-Keynesian results we observe work through the effect of fiscal actions on interest rates and asset prices or rather via their effects on households' perceived permanent income. Moreover, our cross-country evidence concerns exclusively private consumption, not business investment. Both limitations can be overcome by focusing on the evidence for a single country with reliable time-series data, and thus avoiding altogether problems of availability and international comparability of data for wealth. Here we focus on Sweden, and particularly on its 1990-94 fiscal expansion which, in light of Figures 1 and 2, is a good candidate for a non-Keynesian fiscal expansion.

In the last fifteen years the financial position of the Swedish public sector has gone through a true roller-coaster experience. In the mid-1980s, public finances improved spectacularly, only to deteriorate as dramatically after 1989. As shown by Figure 5, between 1985 and 1990 the net debt of the central and local government fell from 47.1 percent to 24.9 percent of GDP, but then climbed back to 67.8 percent of GDP by 1994 - a time pattern dominated by that of the central government's gross debt.

An important preliminary step is to understand the extent to which the worsening of the Swedish budget in the early 1980 s is due to discretionary fiscal actions or rather to the recession. Between 1990 and 1993, Sweden went through the sharpest recession of its recent history. About 50,000 firms went bankrupt, the banking system almost collapsed, half-a- 
million people lost their jobs, taking the total number of those unemployed or on government programs close to 14 percent - an extraordinary figure in a country used to unemployment rates of 2 or 3 percent for decades. Nonetheless, both the data from the OECD and from the Swedish Ministry of Finance confirm that a significant fraction - over half - of the budgetary deterioration cannot be attributed to the recession, but to discretionary policy actions or to peculiar mechanisms of the Swedish tax and transfers system unrelated to the business cycle.

Table 2 shows that, according to OECD data, the unadjusted primary balance of the public sector dropped by 16.2 percentage points of GDP between 1990 and 1993: it went from a surplus of 4.3 percent in 1990 , one of the largest surpluses in the OECD, to a deficit of -11.9 percent in 1993, one of the largest deficits in the OECD. The cyclically-adjusted primary balance fell by 9 percentage points of potential GDP over the same period, from 3.5 percent in 1990 to -6.5 percent in 1993 . So over $1 / 2$ of the deterioration of the primary balance between 1990 and 1993 can be attributed to discretionary policy actions.

In panels $\mathrm{C}$ and $\mathrm{D}$ of Table 2 we report figures provided by the Swedish Ministry of Finance for the interval 1990-94. These figures are based on a different method to partition the deficit into its cyclical and structural components. According to the Ministry's data, between 1990 and 1993 the primary balance deteriorated by 14.1 percent of GDP, and the cyclically-adjusted primary balance by 10.9 percent of GDP. So, although they differ somewhat from the OECD data, the figures from the Ministry of Finance confirm that the recession was not the main cause of the fiscal deterioration..$^{5}$ They attribute $3 / 4$ of the change in the primary deficit to non-cyclical factors - even more than the OECD does.

\footnotetext{
${ }^{5}$ This contrasts with the view taken in Persson (1996).
} 
Behind the worsening of the non-cyclical component of the budget lie discretionary policy actions, such as the tax cut of 1991 and the bailout of major banks in 1991-93. But the worsening of the full-employment balance also reflects the budgetary consequences of the rapid fall in inflation - due to the method used for adjusting tax brackets for inflation, and to the fact that government transfers are adjusted to inflation with a lag. An additional factor was the shift in income distribution towards lower-taxed non-wage income. ${ }^{6}$

Panel B of Table 2 shows that the main culprits for the deterioration of the structural balance have been the decline of indirect tax revenue and "other revenues" (which includes capital taxes, compulsory fees, fines, revenue from publicly owned assets, etc.) and a surge in public spending. But the latter has been due to an increase in transfers, rather than to a bulge of public consumption (the latter actually declines as a fraction of potential output).

Thus the Swedish fiscal expansion of 1989-1994 is not the mirror image of the Danish and Irish successful consolidations of the 1980s. In those cases, the fiscal turnaround was effected not only by raising taxes and slashing transfers, but also by reducing or at least stabilizing public consumption. In the Swedish case most of the action comes from a debt-financed decline in net taxes: as a fraction of potential output, public consumption is virtually stable throughout the period. This makes the Swedish experience ideally suited to test the view that a large cut in net taxes can depress private consumption and investment, rather than stimulate them as suggested by traditional textbook theory. Such non-Keynesian effects can be rationalized by expectational mechanisms of the type suggested by Blanchard (1990) and Sutherland (1995), based on the idea that a tax cut today may mean bad news about tomorrow. They cannot, instead, be explained by changes in expectations about future

\footnotetext{
${ }^{6}$ See OECD Economic Surveys - Sweden, 1991/2 and 1994.
} 
government consumption, which we suggested as a possible motivation for the effects of the Danish and Irish consolidations of the 1980s.

\subsection{The default risk on Swedish public debt}

In the introduction we mentioned that a debt-financed cut in net taxes can depress private consumption, rather than stimulate it, if it brings closer the "day of reckoning" of a default on public debt. The idea is that the default by the government is not the mere canceling of assets and liabilities in the economy, but has potentially devastating real effects, by undermining the solvency of households, companies and financial intermediaries and precipitating a cumulative process of bankruptcies. There is some evidence that in the early 1990s some fear of a sovereign default by the Swedish government indeed started to arise, and increase significantly by the end of 1992 .

The most reliable measure of the expectations of sovereign default can be obtained by comparing the yield to maturity of sovereign debt with that of debt issued by a "sound" foreign issuer, denominated in the same currency and with the same maturity (the identity of currency denomination guarantees that the yield differential does not reflect the expected depreciation of the domestic currency, and therefore the expected monetization of domestic debt). Figure 6 shows the behavior of the differential between a Swedish government 30-year international bond denominated in US dollars and a bond of the same maturity and currency issued by the World Bank. The default premium rises from 20 basis points in 1990 to almost 100 basis points in 1993. After a temporary decline in early 1994, it rises again over 100 basis points in 
September 1995, a level close to the corresponding premium on public debt issued by Italy, whose debt-GDP ratio is about twice that of Sweden.

This may be related to the fact that while Italy has been expected for some time to stabilize its debt-GDP ratio by 1996 (according to the projections of Italian government), until recently all the projections agreed that the Swedish debt-GDP ratio would keep rising steeply. According to the OECD simulations in November 1993, net debt (inclusive of the social security net debt sector) could be stabilized by 1999 only if the primary budget were cut by 1.2 percent per year in 1995-2000, under the optimistic assumptions of an average real GDP growth of 3.5 per year and a real interest rate of 4 percent. ${ }^{7}$ A 1994 study by Credit Suisse First Boston ${ }^{8}$ presented various projections of the Swedish debt-GDP ratio assuming that the primary deficit would be cut by 1.5 percent per year until it were reduced to zero. It concluded that the central government debt-GDP ratio would not be stabilized before 2001 even in the most optimistic scenario considered ( 5 percent nominal growth and 7 percent nominal interest rate). At the time of writing, the view on the ability of the Swedish government to stabilize the debt-GDP ratio is much more favorable: the drastic program of fiscal consolidation proposed by the Social Democratic government which took over in September 1994 implies a reduction of the cyclically-adjusted primary balance of over 6 percent of GDP over the 1995-98 interval. According to the government's own forecasts and those of the OECD, if this program is fully implemented the debt-GDP ratio will be stabilized by 1996 and will decline afterwards. ${ }^{9}$ But

\footnotetext{
${ }^{7}$ OECD Economic Surveys - Sweden, 1994.
}

${ }^{8}$ Credit Suisse First Boston, "Sweden's Public Debt," report issued on 22 July 1994.

${ }^{9}$ OECD Economic Surveys - Sweden, 1995. Lately the financial press has also started to voice cautious optimism on the outlook for Swedish public finances. See, for instance, The Economist, October 14-20, 1995, and Lehman Brothers' Country Study on Sweden, "Moving Away from the Brink," by Keld Holm, 16 August 1995. 
Figure 6 shows that this more favorable view is not yet reflected in our measure of the default risk.

\subsection{The behovior of private consumption, investment and asset prices}

Figure 7 shows that in the 1980s the propensity to consume of Swedish households correlates inversely with the debt-GDP ratio. Consumption boomed in the mid-1980s, in coincidence with a substantial decline of the debt-GDP ratio, and then fell by 13 percentage points between 1989 and 1994 as public debt started to sky-rocket. The same inverse correlation emerges for investment and public debt, both scaled by GDP.

This suggests that private demand may have had an inverse correlation with the large changes in fiscal policy that have characterized Sweden since the beginning of the 1980 s. It remains to be seen if this correlation is still present after we control for other variables which affect private consumption (such as wealth) and investment (such as real interest rates). In fact, the 1980 s have been also characterized by wide swings in the real price of housing and equities and in real interest rates (see figures 8 and 9), and these display an inverse correlation with the debt-GDP ratio.

These gyrations in asset prices are associated with the dramatic developments in monetary and exchange rate policy - the peak in real interest rates coincides with the currency crisis of 1992, and so does the trough in real stock prices - but, to a certain extent, they may also be determined by fiscal policy. In fact, asset prices may be one of the channels through which fiscal impulses have affected private demand. The increase in the debt-GDP ratio since 1989 may have pushed up real interest rates via a standard crowding-out mechanism, triggering a 
decline in consumption via a wealth effect (outweighing the income effect of lower net taxes) and in investment via a higher cost of capital.

However, the discussion of section 1 suggests that, when the debt-GDP ratio is already high, a reduction in net taxes financed by additional debt may have an expectational effect on consumption and investment over and beyond that passing through asset prices. For instance, to repay the implied additional debt, in the future Swedes may have to bear tax distortions far greater than those that they have avoided today. Or they may have to bear the costly consequences of a government default. According to this view, the high deficits of 1989-93 would have led Swedish consumers to reduce their estimate of their permanent disposable income, and thereby their consumption, beyond what can be explained by wealth effects. Similarly, the deficits would have reduced their estimates of the future earnings from productive assets, and thus the profitability of investment, beyond what can be explained by changes in the real interest rate. In what follows we shall attempt to detect if these expectational effects are present after one controls for the effect of asset prices on consumption and investment.

\subsection{Evidence from consumption regressions}

In the estimation of the consumption function we use two different specifications: the structural model proposed by Hayashi (1982) and the less restrictive error-correction approach of Davidson, Hendry et al. (1978). 
In Hayashi's specification, households' consumption of non-durables and services is a function of its own lagged value, of lagged after-tax labor earnings, of current and lagged wealth, and of current an lagged disposable income. Disposable income is included to allow for the possibility that some consumers may be liquidity-constrained or behave myopically. We also estimate the model decomposing total wealth in housing wealth, stocks and other forms of wealth. We do this because houses and stocks are the only items measured at market prices in our wealth series, and therefore may better capture wealth effects arising from changes in interest rates. Moreover, housing wealth can have a different coefficient in view of its lumpiness and low liquidity. The specification is reported at the top of Table 3 (for its derivation see Hayashi (1982)). The model implies a set of non-linear restrictions on the parameters. It is estimated with annual data from 1970 to 1994.

The first two columns report the estimates obtained with non-linear least squares (NLLS). In the regression reported in column 1 only the coefficients on lagged income and lagged consumption are significant. The coefficients of the various components of wealth are not significantly different from each other but are estimated imprecisely. When wealth is entered without being broken down in its components (column 2) its coefficient is estimated more precisely. In this specification, the non-linear constraints implied by the model are not rejected at conventional significance levels.

To allow for the potential simultaneity of wealth and disposable income, the model is reestimated with non-linear instrumental variables (NLIV). The list of instruments includes a constant, a time trend, the first lag of consumption, labor earnings, wealth, disposable income, public consumption, public investment, gross business investment, real money (M3), and the terms of trade. Column 3 of Table 4 reports the estimates with wealth broken down in its components, and column 4 those obtained with total wealth. The main difference relative to 
the NLLS estimates is that now the coefficient of disposable income turns non-significant, while that of stock market wealth becomes larger and significant at the 10 percent level, indicating that simultaneity bias is likely to be present in the NLLS estimates. The result that disposable income does not appear with a significant coefficient in this regression squares with the results for Sweden obtained, among others, by Jappelli and Pagano (1989). The interpretation offered in that study is that Swedish households are forward looking and face no appreciable liquidity constraints, so that their consumption is effectively decoupled from anticipated changes in their disposable income. Finally, column 5 reports the NLIV estimates obtained by dropping disposable income from the list of regressors.

At this point, we ask if, once we control for changes in wealth, a significant fraction of the observed changes in consumption over the interval 1990-94 still remains unexplained. If the expectational mechanism discussed above were at work in those years, the estimated equation - which does not capture such mechanism - should overpredict consumption substantially. So we re-estimate the model up to 1989 according to the specification of column 5 (the estimated coefficients are almost identical to those reported in the table), and compute its dynamic forecasts. In Table 4 we report the actual growth rate of consumption, and the dynamic forecast produced by the model over the 1990-94 interval. For comparison, we also report the corresponding forecasts published by the Swedish Ministry of Finance in December 1990 and those published by the OECD in November 1990. These forecasts differ from ours in two respects: (i) they refer to total consumption, including spending on durable goods, and (ii) are conditional ex ante forecasts, while our out-of-sample forecasts are ex post, i.e. are generated using the actual values of wealth and labor income realized after 1989. In all three cases, consumption is vastly overpredicted. Based on our forecast (which is the most accurate, for the trivial reason that we can condition on the realized values of income and wealth), the 
cumulative overprediction of the consumption of non-durables and services is 3.7 percent in 1994. The Swedish Ministry of Finance overpredicted private consumption in 1992 by 5 percent (as of the end of 1990), and overpredicted the 1993 value by 6.4 percent (as of end of 1991).

Interestingly, the overprediction of consumption occurs also if the consumption function is specified and estimated along the lines proposed by Davidson, Hendry, Srba and Yeo (1978), i.e. positing a long-run relationship between the consumption-income ratio, the wealth-income ratio and other variables, and then specifying the short-run dynamics of consumption via an error-correction model (ECM). When we adopt this specification, the cumulative overprediction of consumption in 1994 is 6.7 percent of its initial level. ${ }^{10}$

Most other econometric studies agree with the finding that the Swedish consumption function features an abnormally large negative shock in the early 1990s, although the explanations so far offered differ from ours. Barot and Kanis (1993) estimate a consumption function with the ECM approach on semiannual and quarterly data for total consumption, as well as for expenditure on non-durables, cars and other durables separately, and find that the regressions estimated on semi-annual data tend to overpredict grossly in out-of-sample dynamic forecasts for the early 1990s. Barot (1995) reports that this overprediction disappears if the regressors include the unemployment rate, meant to be a proxy for the

\footnotetext{
${ }^{10}$ To build these forecasts we proceed according to the standard Engle-Granger two-stage method. First, we estimate the long-run relationship between consumption, the three components of wealth and disposable income with two-stage least squares. All variables are per-capite and transformed into logarithms, and the estimation is performed on the entire sample. The list of regressors include disposable income, rather than netof-tax labor income, because the latter is not available for 1994. The instruments used are the lagged value of each regressor, plus the constant, The results from a Dickey-Fuller test on the residuals indicate that all five variables (consumption, disposable income and the three companents of wealth) are cointegrated.

Next, we estimate the ECM regressing the growth rate of consumption on the growth rates of the four regressors, plus a constant and the residuals from the first regression. This specification is estimated up to 1989. Finally we compute the dynamic forecasts from the ECM model for the years 1990-94. We do so by using the actual realizations of each right-hand-side variable and the actual residuals for those years obtained from the long-run specification, i.e. from the first regression.
} 
employment and income risk faced by Swedish households. The reason why the overprediction disappears is easily understood from the time-series behavior of the unemployment rate in Sweden: it fluctuates between 1 and 2 percent in the 1970s and 1980s, and then rises steeply to over 12 percent in the early 1990s, so that in effect it acts as a dummy variable for those years. But to some extent the rise in unemployment may be a result of the fall in consumption expenditure, rather than its cause.

Berg and Bergström (1995) also estimated an ECM model of the consumption function, disaggregating housing and financial net wealth, and find evidence that the dramatic increase in saving is due to the tax reform of 1991 . Their evidence agrees with the following possible account of the Swedish recession (Berg, 1994; Jonung and Stymne, 1995). The revision of the tax system in 1990 and 1991 lowered the capital income tax, introducing a separate 30 percent flat rate on capital income, and reduced the deductibility tax rate of capital losses and household interest expenses to 30 percent. The implied increase in the after-tax rate of interest prompted Swedish households to step up their saving and reduce their indebtedness sharply. The fall in household demand triggered a deflation of house prices, further enhanced by the increase in the real interest rates stemming from the policy of pegging the Krona to the Deutsche Mark. The fall in asset prices in turn contributed to the reduction of private demand via wealth effects.

However, more recent work by Agell, Berg and Edin (1995) casts some doubt on this account, indicating that the tax reform alone cannot explain the shock to consumption. They note that even though the tax reform coincided with the exceptional consumption decline of the early 1990s, the implied increase in after-tax real interest rates cannot have had a large impact on consumption, owing to its small interest sensitivity. They maintain that, to the extent that it mattered, the tax reform affected consumption mainly via its impact on the price 
of assets and the implied wealth effects. But even after accounting for these and experimenting "with several explanatory factors often proposed in the literature, there still remain large negative errors in the consumption function for 1992-93" (p. 24). They conclude that "there is something else going on. Either there is some important omitted variable, or consumption behaviour has changed in a more profound way during the economic depression of the 1990s" (p. 25).

In conclusion, there is a rather firm consensus that during the Swedish fiscal expansion of the early 1990s a large negative error appears in the consumption function, quite independently of the specification used to estimate it. There is less consensus about how this error should be interpreted, but it is clear that the most obvious candidates (wealth effects and after-tax real interest rate effects) are not sufficient to explain it. Under the assumption of rational expectations, this error may reflect a large downward revision of permanent disposable income, which affected the consumption choices of Swedish households over and beyond the negative effects of the drop in real asset prices. 11 We suggest that this downward revision in permanent disposable income may have been triggered by the government's fiscal laxitude in the early 1990 s, which - as seen above - is largely attributable to deliberate policy actions and has led Sweden to accumulate public debt at a breakneck rate. So the evidence is consistent with the idea that the fiscal expansion might have actually depressed private consumption, both by reducing the shadow value of human wealth and, more conventionally, by depressing the market value of non-human wealth.

\footnotetext{
${ }^{11}$ Alternatively, the error may reflect an increase in the perceived variance of permanent disposable income (as suggested by Barot, 1995) or a change in the preferences of Swedish households. Empirically, it may be very hard to disentangle these three alternative explanations - changes in expectations about the level of disposable income, in its perceived variance and in preferences - since they all refer to unobservables.
} 


\subsection{Evidence from investment regressions}

For investment we adopt a simple predictive technique. We estimate on yearly data a simple reduced form expression in which gross real business investment is expressed as function of its own lags, of the lagged values of real GDP and of the real interest rate. ${ }^{12}$ In our preferred specification for the period 1970-89 the regressors include the first lag of investment, three lags of GDP and the first lag of the real interest rate. The estimated regression is displayed at the top of Table 5. Its adjusted $R^{2}$ is 0.940 .

When this equation is used to form fitted values and dynamic forecasts for the period 199094, it massively overpredicts, as shown in Table 5. In fact, when we re-estimate our reduced form for investment over the whole 1970-94 sample and test for structural stability, we find that the relationship has undergone a structural break in 1990 . The corresponding forecasts of the Swedish Ministry of Finance and those of the OECD also grossly overpredict for most of the 4 years. So, just as in the consumption function, also in the investment function there seems to be a large negative error in the early 1990 s. This suggests that entrepreneurs may have perceived a drop in the value of productive capital over and beyond that attributable to the increase of the real interest rate, which is accounted for in the regression. Witness to this, the forecast errors of the regression are substantially reduced if we introduce the stock price index divided by the investment deflator (a rough estimate of Tobin's average " $q$ ") as an additional regressor. Again, as for consumption, it is plausible that the runaway fiscal expansion is the source of such entrepreneurial pessimism.

\footnotetext{
${ }^{12}$ The real interest rate is measured as $(1+i) /\left(1+\pi^{9}\right)-1$, where $i=$ long-term debt yield and $\pi^{e}=$ expected inflation, computed as the weighed average of the one, two and three steps ahead dynamic forecasts obtained from a first-order autoregression of the inflation rate.
} 


\section{Conclusions}

In our earlier paper on the Danish and Irish experience of the 1980 s we documented two cases in which a drastic fiscal consolidation was associated with a surprisingly large expansion in private demand, which considerably helped the government in reducing the debt-GDP ratio. Since that evidence was limited to two - albeit striking - episodes, one could question whether these non-Keynesian effects of fiscal policy would survive a more thorough empirical investigation.

In the present paper we have attempted to cast a wider net, using cross-country data for 19 OECD countries and analyzing in detail the Swedish fiscal expansion of the early 1990s. Our main results are:

(i) fiscal policy changes can indeed have non-Keynesian effects if they are sufficiently large and protracted;

(ii) these effects are present not only if the fiscal tumaround is obtained through changes in public consumption, but also if it achieved through changes in taxes and transfers: this is consistent both with our cross-country evidence and with the evidence for Sweden in the early 1990 , where the fiscal impulse consisted mainly of cuts in net taxes, rather than changes in government consumption;

(iii) non-Keynesian effects work, at least partly, by affecting private sector expectations about the future income from labor and capital, and not solely via the implied changes in the real interest rate and asset values. This point, which already surfaced in our former study on the Danish and Irish consolidations, appears to be relevant also for the Swedish fiscal expansion of the early 1990 s.

\section{References}


Agell, Jonas, Lennart Berg and Per-Anders Edin (1995), "The Swedish Boom to Bust Cycle: Tax reform, Consumption and Asset Structure," forthcoming in Swedish Economic Policy Review.

Alesina, Alberto, and Roberto Perotti (1995), "Fiscal Expansions and Fiscal Adjustments in OECD Countries," forthcoming in Economic Policy.

Barot, Bharat (1995), "The Role of Wealth in the Aggregate Consumption Function Using an Error Correction Aprroach: Swedish Experience from the Years 1970-1993," mimeo, National Institute of Economic Research.

Berg, Lennart (1994), "Household Savings and Debts: The Experience of the Nordic Countries," Oxford Review of Economic Policy 10(2), $42-53$.

Berg, Lennart, and Reinhold Bergström (1995), "Housing and Financial Wealth, Financial Deregulation and Consumption - The Swedish Case," Scandinavian Journal of Economics 97(3), 421-439.

Bertola, Giuseppe, and Allan Drazen (1993), "Trigger Points and Budget Cuts: Explaining the Effects of Fiscal Austerity," American Economic Review 83(1), 1170-88.

Blanchard, Olivier (1990), “Comment”, NBER Macroeconomics Annual, 111-116.

Blinder, Alan S., and Angus Deaton (1985), "The Time Series Consumption Function Revisited," The Brokings Papers on Economic Activity 2, 465-511.

Davidson, James E. H., David F. Hendry, Frank Srba, and Stephen Yeo (1978), "Econometric Modelling of the Aggregate Time-Series Relationship between Consumers' Expenditure and Income in the U.K.," The Economic Journal 88, 661-692.

Drazen, Allan (1990), “Comment”, NBER Macroeconomics Anmual, 117-122.

Feldstein, Martin (1982), "Government Deficits and Aggregate Demand," Journal of Monetary Economy 9(1), 1-20.

Giavazzi, Francesco, and Marco Pagano (1990), "Can Severe Fiscal Contractions be Expansionary? Tales of Two Small European Countries," NBER Macroeconomics Annual, 75-116.

Jappelli, Tullio, and Marco Pagano (1989), "Consumption and Capital Market Imperfections: An International Comparison," The American Economic Review 79(5), 1088-1105, December.

Jonung, Lars, and Joakim Stymne (1995), "The Great Regime Shift: Asset Markets and Economic Activity in Sweden, 1985-93," forthcoming in Capie, Forrest and Wood (eds.), Credit Crunches and the Real Economy, London: Macmillan. 
Kanis, Alfred, and Bharat Barot (1993), "On Determinants of Private Consumption in Sweden," National Institute of Economic Reasearch, Working Paper No. 34, October.

Persson, Mats (1996), "Swedish Government Debts and Deficits," Swedish Economic Policy Review 3, May.

Sutherland, Allan (1995), "Fiscal Crises and Aggregate Demand: Can High Public Debt Reverse the Effects of Fiscal Policy?," mimeo, University of York, February. 
Table 1. Consumption regressions, OECD countries panel data, 1970-92

Panel $A$. Results of OLS and robust extimation

The dependent variable is the change in the logarithm of real per capite consumption $\left(\Delta c_{t}\right)$ and the specification is that of equation ( $\left.1^{\prime}\right)$ in the text. The values in parentheses below the estimated coefficients are $t$-statistics. All regressions include a constant and country dummies. The regressions in columns 2 and 4 of Panel A and in columns 3 and 5 of Panel B also include year dummies. The data set includes 367 yearly observations over 1970-92 for the following 19 countries: Austria, Australia, Belgium, Canada, Denmark, Finland, France, Germany, Greece, Ireland, Italy, Japan, Netherlands, Norway, Portugal, Spain, Sweden, UK, USA.

\begin{tabular}{|c|c|c|c|c|}
\hline $\begin{array}{c}\text { Regression and estimation method } \rightarrow \\
\text { Independent variable } \\
\downarrow\end{array}$ & $\begin{array}{l}\text { (1) } \\
\text { OLS }\end{array}$ & $\begin{array}{l}\text { (2) } \\
\text { OLS }\end{array}$ & $\begin{array}{c}\text { (3) } \\
\text { Robust } \\
\text { estimation }\end{array}$ & $\begin{array}{c}\text { (4) } \\
\text { Robust } \\
\text { estimation }\end{array}$ \\
\hline $\begin{array}{l}\text { 1. Lagged consumption: } \\
c_{t-1}\end{array}$ & $\begin{array}{c}-0.26 \\
(-8.37) \\
\end{array}$ & $\begin{array}{c}-0.28 \\
(-8.57) \\
\end{array}$ & $\begin{array}{c}-0.22 \\
(-7.74) \\
\end{array}$ & $\begin{array}{c}-0.27 \\
(-9.29) \\
\end{array}$ \\
\hline $\begin{array}{l}\text { 2. Income changes: } \\
\Delta y_{t}\end{array}$ & $\begin{array}{c}0.53 \\
(14.99) \\
\end{array}$ & $\begin{array}{c}0.50 \\
(13.57)\end{array}$ & $\begin{array}{c}0.52 \\
(16.38) \\
\end{array}$ & $\begin{array}{c}0.48 \\
(14.50) \\
\end{array}$ \\
\hline $\begin{array}{l}\text { 3. Lagged income: } \\
y_{t-1}\end{array}$ & $\begin{array}{c}0.24 \\
(7.51) \\
\end{array}$ & $\begin{array}{c}0.26 \\
(8.03) \\
\end{array}$ & $\begin{array}{c}0.18 \\
(6.07) \\
\end{array}$ & $\begin{array}{c}0.21 \\
(7.37) \\
\end{array}$ \\
\hline $\begin{array}{l}\text { 4. World income changes: } \\
\Delta y_{t}^{w}\end{array}$ & $\begin{array}{c}0.10 \\
(2.23)\end{array}$ & & $\begin{array}{l}0.10 \\
(2.60)\end{array}$ & \\
\hline $\begin{array}{l}\text { 5. Lagged world income: } \\
y_{t-1}^{w}\end{array}$ & $\begin{array}{l}0.05 \\
(2.13)\end{array}$ & & $\begin{array}{c}0.04 \\
(1.96)\end{array}$ & \\
\hline \multicolumn{5}{|l|}{ Fiscal variables in "normal times" $\left(d_{t}=0\right)$ : } \\
\hline $\begin{array}{l}\text { 6. Tax changes: } \\
\left(1-d_{t}\right) \cdot \Delta \tau_{t}\end{array}$ & $\begin{array}{c}0.01 \\
(0.29) \\
\end{array}$ & $\begin{array}{c}0.02 \\
(0.50) \\
\end{array}$ & $\begin{array}{c}-0.01 \\
(-0.34) \\
\end{array}$ & $\begin{array}{c}0.02 \\
(0.55) \\
\end{array}$ \\
\hline $\begin{array}{l}\text { 7. Lagged taxes: } \\
\left(1-d_{t}\right) \cdot \tau_{t-1} \\
\end{array}$ & $\begin{array}{c}-0.03 \\
(-1.68)\end{array}$ & $\begin{array}{c}-0.04 \\
(-1.93)\end{array}$ & $\begin{array}{c}-0.02 \\
(-1.24) \\
\end{array}$ & $\begin{array}{c}-0.02 \\
(-1.04)\end{array}$ \\
\hline $\begin{array}{l}\text { 8. Transfer changes: } \\
\left(1-d_{t}\right) \cdot \Delta t r_{t}\end{array}$ & $\begin{array}{c}0.01 \\
(0.35) \\
\end{array}$ & $\begin{array}{l}-0.01 \\
(0.30)\end{array}$ & $\begin{array}{c}0.02 \\
(0.82) \\
\end{array}$ & $\begin{array}{c}-0.02 \\
(-0.72)\end{array}$ \\
\hline $\begin{array}{l}\text { 9. Lagged transfers: } \\
\left(1-d_{t}\right) \cdot t r_{t-1}\end{array}$ & $\begin{array}{c}0.02 \\
(1.77) \\
\end{array}$ & $\begin{array}{c}0.01 \\
(0.81) \\
\end{array}$ & $\begin{array}{c}0.02 \\
(2.18) \\
\end{array}$ & $\begin{array}{c}0.01 \\
(1.11)\end{array}$ \\
\hline $\begin{array}{l}\text { 10. Public consumption changes: } \\
\left(1-d_{t}\right) \cdot \Delta g_{t}\end{array}$ & $\begin{array}{c}0.09 \\
(1.85) \\
\end{array}$ & $\begin{array}{c}0.09 \\
(1.78)\end{array}$ & $\begin{array}{c}0.10 \\
(2.51) \\
\end{array}$ & $\begin{array}{c}0.11 \\
(2.50) \\
\end{array}$ \\
\hline $\begin{array}{l}\text { 11. Lagged public consumption: } \\
\left(1-d_{t}\right) \cdot g_{t-1}\end{array}$ & $\begin{array}{c}0.01 \\
(0.72)\end{array}$ & $\begin{array}{c}0.01 \\
(0.56) \\
\end{array}$ & $\begin{array}{c}0.01 \\
(0.72) \\
\end{array}$ & $\begin{array}{c}0.01 \\
(0.59) \\
\end{array}$ \\
\hline \multicolumn{5}{|l|}{ Fiacal variables outside "normal times" $\left(d_{t}=1\right)$ : } \\
\hline $\begin{array}{l}\text { 12. Tax changes: } \\
d_{t} \cdot \Delta \tau_{t}\end{array}$ & $\begin{array}{r}-0.04 \\
(-1.24) \\
\end{array}$ & $\begin{array}{c}-0.03 \\
(-0.96) \\
\end{array}$ & $\begin{array}{l}0.002 \\
(0.06) \\
\end{array}$ & $\begin{array}{c}0.01 \\
(0.42) \\
\end{array}$ \\
\hline $\begin{array}{l}\text { 13. Lagged taxes: } \\
d_{t} \cdot \tau_{t-1}\end{array}$ & $\begin{array}{c}0.05 \\
(2.41) \\
\end{array}$ & $\begin{array}{c}0.04 \\
(2.11) \\
\end{array}$ & $\begin{array}{c}0.02 \\
(1.26)\end{array}$ & $\begin{array}{c}0.03 \\
(1.51) \\
\end{array}$ \\
\hline $\begin{array}{l}\text { 14. Transfer changes: } \\
d_{t} \cdot \Delta r_{t}\end{array}$ & $\begin{array}{c}0.02 \\
(0.61) \\
\end{array}$ & $\begin{array}{c}-0.01 \\
(-0.23)\end{array}$ & $\begin{array}{c}0.09 \\
(3.78) \\
\end{array}$ & $\begin{array}{c}0.03 \\
(1.39)\end{array}$ \\
\hline $\begin{array}{l}\text { 15. Lagged transfers: } \\
d_{t} \cdot t_{t-1}\end{array}$ & $\begin{array}{c}-0.03 \\
(-2.64)\end{array}$ & $\begin{array}{c}-0.05 \\
(-3.20)\end{array}$ & $\begin{array}{c}-0.01 \\
(-0.99)\end{array}$ & $\begin{array}{c}-0.02 \\
(-1.66)\end{array}$ \\
\hline $\begin{array}{l}\text { 16. Public consumption changes: } \\
d_{t} \cdot \Delta g_{t}\end{array}$ & $\begin{array}{c}-0.10 \\
(-2.22) \\
\end{array}$ & $\begin{array}{c}-0.10 \\
(-2.09) \\
\end{array}$ & $\begin{array}{c}-0.14 \\
(-3.30) \\
\end{array}$ & $\begin{array}{c}-0.12 \\
(-2.88) \\
\end{array}$ \\
\hline $\begin{array}{l}\text { 17. Lagged public consumption: } \\
d_{t} \cdot g_{t-1}\end{array}$ & $\begin{array}{c}-0.02 \\
(-1.34)\end{array}$ & $\begin{array}{c}-0.03 \\
(-1.50)\end{array}$ & $\begin{array}{r}-0.004 \\
(-0.25) \\
\end{array}$ & $\begin{array}{c}-0.01 \\
(-0.56)\end{array}$ \\
\hline 18. Calendar year dummies: joint $p$-value & & 0.002 & & 0.0003 \\
\hline Adjusted $R^{2}$ & 0.660 & 0.697 & & \\
\hline
\end{tabular}


(Table 1 continued)

Panel B. Results of 2SLS estimation

\begin{tabular}{|c|c|c|c|c|c|}
\hline $\begin{array}{c}\text { Regression and estimation method } \rightarrow \\
\text { Independent variable } \\
\downarrow\end{array}$ & $\begin{array}{l}\text { (1) } \\
\text { 2SLS }\end{array}$ & $\begin{array}{l}\text { (2) } \\
\mathbf{2 S L S}\end{array}$ & $\begin{array}{l}(3) \\
\mathbf{2 S L S}^{2}\end{array}$ & $\begin{array}{l}(4) \\
2 S^{3} S^{3}\end{array}$ & $\begin{array}{l}(\mathbf{( 5 )} \\
\mathbf{2 S L S ^ { 3 }}\end{array}$ \\
\hline $\begin{array}{l}\text { 1. Lagged consumption: } \\
c_{t-1}\end{array}$ & $\begin{array}{c}-0.25 \\
(-4.74)\end{array}$ & $\begin{array}{l}-0.29 \\
(-7.89)\end{array}$ & $\begin{array}{c}-0.32 \\
(-7.45)\end{array}$ & $\begin{array}{c}-0.27 \\
(-8.21)\end{array}$ & $\begin{array}{c}-0.30 \\
(-8.22)\end{array}$ \\
\hline $\begin{array}{l}\text { 2. Income changes: } \\
\Delta y_{t}\end{array}$ & $\begin{array}{c}0.52 \\
(5.04)\end{array}$ & $\begin{array}{c}0.53 \\
(9.50)\end{array}$ & $\begin{array}{l}0.45 \\
(6.53)\end{array}$ & $\begin{array}{c}0.53 \\
(13.38)\end{array}$ & $\begin{array}{c}0.56 \\
(10.26)\end{array}$ \\
\hline $\begin{array}{l}\text { 3. Lagged income: } \\
y_{t-1}\end{array}$ & $\begin{array}{l}0.18 \\
(2.16)\end{array}$ & $\begin{array}{c}0.28 \\
(6.81)\end{array}$ & $\begin{array}{c}0.31 \\
(7.00)\end{array}$ & $\begin{array}{l}0.26 \\
(7.36)\end{array}$ & $\begin{array}{l}0.30 \\
(7.81)\end{array}$ \\
\hline $\begin{array}{l}\text { 4. World income changes: } \\
\Delta y_{t}^{w}\end{array}$ & $\begin{array}{l}0.12 \\
(1.81)\end{array}$ & $\begin{array}{c}0.11 \\
(2.18)\end{array}$ & & $\begin{array}{c}0.11 \\
(2.51)\end{array}$ & \\
\hline $\begin{array}{l}\text { 5. Lagged world income: } \\
y_{t-1}^{w}\end{array}$ & $\begin{array}{c}0.03 \\
(0.94)\end{array}$ & $\begin{array}{l}0.03 \\
(1.08)\end{array}$ & & $\begin{array}{c}0.05 \\
(2.15)\end{array}$ & \\
\hline \multicolumn{6}{|l|}{ Fiscal variables in "normal times" $\left(d_{t}=0\right)$; } \\
\hline $\begin{array}{l}\text { 6. Tax changes: } \\
\left(1-d_{t}\right) \cdot \Delta \tau_{t}\end{array}$ & $\begin{array}{c}0.09 \\
(0.51)\end{array}$ & $\begin{array}{c}0.02 \\
(0.22)\end{array}$ & $\begin{array}{c}0.10 \\
(0.86)\end{array}$ & $\begin{array}{c}-0.02 \\
(-0.53)\end{array}$ & $\begin{array}{l}-0.03 \\
(-0.54)\end{array}$ \\
\hline $\begin{array}{l}\text { 7. Lagged taxes: } \\
\left(1-d_{t}\right) \cdot \tau_{t-1}\end{array}$ & $\begin{array}{c}0.04 \\
(0.61)\end{array}$ & $\begin{array}{l}-0.03 \\
(-1.13)\end{array}$ & $\begin{array}{l}-0.04 \\
(-1.20)\end{array}$ & $\begin{array}{l}-0.05 \\
(-2.18)\end{array}$ & $\begin{array}{c}-0.07 \\
(-2.93)\end{array}$ \\
\hline $\begin{array}{l}\text { 8. Transfer changes: } \\
\left(1-d_{t}\right) \cdot \Delta r_{t}\end{array}$ & $\begin{array}{c}0.17 \\
(1.10)\end{array}$ & $\begin{array}{c}0.16 \\
(2.38)\end{array}$ & $\begin{array}{c}0.06 \\
(0.75)\end{array}$ & $\begin{array}{c}0.03 \\
(0.72)\end{array}$ & $\begin{array}{c}-0.04 \\
(-0.76)\end{array}$ \\
\hline $\begin{array}{l}\text { 9. Lagged transfers: } \\
\left(1-d_{t}\right) \cdot t_{t-1}\end{array}$ & $\begin{array}{c}0.03 \\
(0.95)\end{array}$ & $\begin{array}{l}0.04 \\
(2.62)\end{array}$ & $\begin{array}{c}0.02 \\
(0.80)\end{array}$ & $\begin{array}{c}0.03 \\
(1.94)\end{array}$ & $\begin{array}{c}0.02 \\
(1.27)\end{array}$ \\
\hline $\begin{array}{l}\text { 10. Public consumption changes: } \\
\left(1-d_{t}\right) \cdot \Delta g_{t}\end{array}$ & $\begin{array}{c}-0.12 \\
(-0.59)\end{array}$ & $\begin{array}{c}0.01 \\
(0.11)\end{array}$ & $\begin{array}{c}0.02 \\
(0.12)\end{array}$ & $\begin{array}{c}0.15 \\
(2.55)\end{array}$ & $\begin{array}{c}0.18 \\
(2.24)\end{array}$ \\
\hline $\begin{array}{l}\text { 11. Lagged public consumption: } \\
\left(1-d_{t}\right) \cdot g_{t-1}\end{array}$ & $\begin{array}{c}-0.03 \\
(-0.93)\end{array}$ & $\begin{array}{c}-0.01 \\
(-0.35)\end{array}$ & $\begin{array}{l}-0.001 \\
(-0.03)\end{array}$ & $\begin{array}{c}0.02 \\
(1.15) \\
\end{array}$ & $\begin{array}{c}0.02 \\
(1.22)\end{array}$ \\
\hline \multicolumn{6}{|l|}{ Fiscal variables outside "normal times" $\left(d_{t}=1\right)$ : } \\
\hline $\begin{array}{l}\text { 12. Tax changes: } \\
d_{t} \cdot \Delta \tau_{t}\end{array}$ & $\begin{array}{l}.004 \\
(0.02)\end{array}$ & $\begin{array}{c}0.04 \\
(0.57)\end{array}$ & $\begin{array}{c}0.10 \\
(1.18)\end{array}$ & $\begin{array}{c}-0.01 \\
(-0.20)\end{array}$ & $\begin{array}{c}0.02 \\
(0.47)\end{array}$ \\
\hline $\begin{array}{l}\text { 13. Lagged taxes: } \\
d_{t} \cdot \tau_{t-1}\end{array}$ & $\begin{array}{l}0.07 \\
(1.65)\end{array}$ & $\begin{array}{l}0.08 \\
(2.91)\end{array}$ & $\begin{array}{l}0.09 \\
(2.79)\end{array}$ & $\begin{array}{l}0.03 \\
(1.47)\end{array}$ & $\begin{array}{c}0.05 \\
(1.85)\end{array}$ \\
\hline $\begin{array}{l}\text { 14. Transfer changes: } \\
d_{t} \cdot \Delta t r_{t}\end{array}$ & $\begin{array}{l}0.30 \\
(1.66)\end{array}$ & $\begin{array}{c}0.04 \\
(0.62)\end{array}$ & $\begin{array}{l}-0.07 \\
(-0.86)\end{array}$ & $\begin{array}{c}-0.03 \\
(-0.91)\end{array}$ & $\begin{array}{c}-0.10 \\
(-2.55)\end{array}$ \\
\hline $\begin{array}{l}\text { 15. Lagged transfers: } \\
d_{t} \cdot t_{t-1}\end{array}$ & $\begin{array}{c}0.01 \\
(0.52)\end{array}$ & $\begin{array}{c}-0.03 \\
(-1.49)\end{array}$ & $\begin{array}{r}-0.06 \\
(-2.60)\end{array}$ & $\begin{array}{c}-0.03 \\
(-2.32)\end{array}$ & $\begin{array}{c}-0.07 \\
(-3.97)\end{array}$ \\
\hline $\begin{array}{l}\text { 16. Public consumption changes: } \\
d_{t} \cdot \Delta g_{t}\end{array}$ & $\begin{array}{c}-0.02 \\
(-0.10)\end{array}$ & $\begin{array}{r}-0.26 \\
(-2.35)\end{array}$ & $\begin{array}{l}-0.30 \\
(-2.23)\end{array}$ & $\begin{array}{l}-0.09 \\
-1.46)\end{array}$ & $\begin{array}{c}-0.19 \\
(-2.51)\end{array}$ \\
\hline $\begin{array}{l}\text { 17. Lagged public consumption: } \\
d_{t} \cdot g_{t-1}\end{array}$ & $\begin{array}{c}-0.05 \\
(-1.48)\end{array}$ & $\begin{array}{c}-0.05 \\
(-2.46)\end{array}$ & $\begin{array}{r}-0.05 \\
(-2.12) \\
\end{array}$ & $\begin{array}{l}-0.01 \\
(-0.47)\end{array}$ & $\begin{array}{c}-0.02 \\
(-0.72)\end{array}$ \\
\hline 18. Calendar year dummies: joint $p$-value & & & 0.02 & & 0.02 \\
\hline Adjusted $R^{2}$ & 0.501 & 0.574 & 0.581 & 0.614 & 0.665 \\
\hline
\end{tabular}

${ }^{1}$ List of instruments: constant; lagged levels of all the regressors; year and country dummies; current change in world income.

${ }^{2}$ List of instruments: constant; lagged levels of all the regressors; year and country dummies; current change and lagged level of world income, both interacted with country dummies.

${ }^{3}$ List of instruments: constant; year and country dummies; lagged levels of all the regressors, interacted with country dummies. 
Table 2. Financial position of the Swedish public sector, 1986-1994

Panel A: Unadjusted figures as percent of GDP, OECD data

\begin{tabular}{|lcccccccc|}
\hline & 1987 & 1988 & 1989 & 1990 & 1991 & 1992 & 1993 & 1994 \\
\hline $\begin{array}{l}\text { Tax revenue + social } \\
\text { pecurity contributions }\end{array}$ & 62.4 & 62.0 & 63.7 & 63.3 & 60.3 & 59.8 & 59.2 & 58.4 \\
\hline $\begin{array}{l}\text { Public spending } \\
\text { (excluding interest) }\end{array}$ & 56.9 & 58.1 & 58.0 & 59.0 & 61.4 & 67.2 & 71.1 & 66.0 \\
$\begin{array}{l}\text { of which: consumption } \\
\text { Primary balance }\end{array}$ & 26.7 & 26.0 & 25.9 & 27.2 & 27.0 & 27.9 & 28.0 & 27.3 \\
\hline Net interest & 5.5 & 3.9 & 5.7 & 4.3 & -1.1 & -7.4 & -11.9 & -7.6 \\
\hline Total balance & -1.4 & -0.5 & -0.4 & -0.1 & -0.1 & -0.1 & -1.5 & -2.8 \\
\hline
\end{tabular}

Panel B: Cyclically adjusted figures as a percent of potential GDP, OECD data

\begin{tabular}{|c|c|c|c|c|c|c|c|c|}
\hline & 1987 & 1988 & 1989 & 1990 & 1991 & 1992 & 1993 & 1994 \\
\hline $\begin{array}{l}\text { Tax revenue plus social } \\
\text { security contributions }\end{array}$ & 60.1 & 63.9 & 62.1 & 65.1 & 62.9 & 61.6 & 57.8 & 54.6 \\
\hline $\begin{array}{l}\text { of which: direct taxes } \\
\text { indirect taxes } \\
\text { soc. sec. contrib. } \\
\text { other revenues }\end{array}$ & $\begin{array}{r}23.4 \\
17.3 \\
13.7 \\
5.7 \\
\end{array}$ & $\begin{array}{r}23.8 \\
16.4 \\
13.9 \\
9.8 \\
\end{array}$ & $\begin{array}{r}24.7 \\
16.2 \\
15.0 \\
6.2\end{array}$ & $\begin{array}{r}22.9 \\
17.1 \\
15.4 \\
9.6\end{array}$ & $\begin{array}{l}19.7 \\
17.7 \\
15.4 \\
10.0\end{array}$ & $\begin{array}{l}20.5 \\
16.2 \\
14.9 \\
10.0\end{array}$ & $\begin{array}{r}21.5 \\
15.5 \\
14.3 \\
6.5 \\
\end{array}$ & $\begin{array}{r}21.1 \\
14.6 \\
14.2 \\
4.8 \\
\end{array}$ \\
\hline $\begin{array}{l}\text { Public spending } \\
\text { (excluding interest) }\end{array}$ & 60.6 & 59.7 & 60.0 & 61.6 & 61.9 & 64.1 & 64.3 & 64.2 \\
\hline of which: consumption & 27.2 & 26.6 & 27.1 & 28.6 & 27.8 & 27.4 & 26.6 & 26.5 \\
\hline Primary balance & -0.5 & 4.2 & 2.1 & 3.5 & 1.0 & -2.5 & -6.5 & -9.6 \\
\hline
\end{tabular}

Panel C: Unadjusted figures as a percent of GDP, Ministry of Finance data ${ }^{1}$

\begin{tabular}{|lccccc|}
\hline & 1990 & 1991 & 1992 & 1993 & 1994 \\
\hline Primary balance & 4.3 & 2.2 & -5.4 & -9.8 & -5.4 \\
\hline Net interest & -0.1 & -3.3 & -2.4 & -3.6 & -5.0 \\
\hline Total balance & 4.2 & -1.1 & -7.8 & -13.4 & -10.4 \\
\hline
\end{tabular}

Panel D: Cyclically adjusted figures as a percent of GDP, Ministry of Finance data ${ }^{1}$

\begin{tabular}{|llllll|}
\hline & 1990 & 1991 & 1992 & 1993 & 1994 \\
\hline Primary balance & 3.5 & 1.7 & -4.7 & -7.4 & -3.5 \\
\hline
\end{tabular}

1 Since the Swedish Ministry of Finance has provided data only for the changes of the primary balance and net interest, we have used the OECD data for 1990 as starting values for the levels of these items. 


\section{TABLE 3}

\section{Consumption function estimates for Sweden}

The regression equation is specified as follows: $C(t)=(1+\delta) C(t-1)+6\{A(t)-(1+\delta)[A(t-1)+w(t-1)]\}+\beta$ $\{H(t)-(1+\delta)[H(t-1)+w(t-1)]\}+\gamma\{\mathbf{S}(t)-(1+\delta)[\mathbf{S}(t-1)]+\mu[Y(t)-(1+\delta) Y(t-1)+w(t-1)]\}$, where $C=$ consumption expenditure on non-durables and services, $A=$ non-human wealth excluding housing and stock market wealth, $H=$ housing wealth, $w=$ net-of-tax labor earnings, $Y=$ household disposable income. All variables are deflated by the deflator of non-durables and services and divided by the population. The sample comprises yearly data from 1970 to 1994 (provided by Bharat Barot, National Institute of Economic Research, Stockholm). The values displayed in parentheses below the estimated coefficients are $t$-statistics. In columns 2,4 and 5 the coefficients $6, f y$ and $\gamma$ are constrained to be equal.

\begin{tabular}{|c|c|c|c|c|c|}
\hline $\begin{array}{c}\text { Regression } \\
\text { and estimation } \\
\text { method } \rightarrow \\
\text { Parameters } \\
\downarrow\end{array}$ & $\begin{array}{c}\text { (1) } \\
\text { NLLS }\end{array}$ & $\begin{array}{c}\text { (2) } \\
\text { NLLS }\end{array}$ & $\begin{array}{c}\text { (3) } \\
\text { NLIV }\end{array}$ & $\begin{array}{c}\text { (4) } \\
\text { NLIV }\end{array}$ & $\begin{array}{c}\text { (5) } \\
\text { NLIV }\end{array}$ \\
\hline $1+\delta$ & $\begin{array}{c}1.02 \\
(33.38)\end{array}$ & $\begin{array}{c}1.02 \\
(109.43)\end{array}$ & $\begin{array}{c}1.03 \\
(33.24)\end{array}$ & $\begin{array}{c}1.03 \\
(111.50)\end{array}$ & $\begin{array}{c}1.03 \\
(113.79)\end{array}$ \\
\hline$\theta=\beta=\gamma$ & & $\begin{array}{c}0.01 \\
(2.15)\end{array}$ & & $\begin{array}{c}0.02 \\
(2.25)\end{array}$ & $\begin{array}{c}0.02 \\
(2.44)\end{array}$ \\
\hline$\theta$ & $\begin{array}{c}-0.02 \\
(-0.71)\end{array}$ & & $\begin{array}{c}-0.03 \\
(-1.14)\end{array}$ & & \\
\hline $\boldsymbol{\beta}$ & $\begin{array}{c}0.01 \\
(0.89)\end{array}$ & & $\begin{array}{c}0.01 \\
(0.62)\end{array}$ & & \\
\hline$\gamma$ & $\begin{array}{c}0.02 \\
(1.13)\end{array}$ & & $\begin{array}{c}0.05 \\
(1.74)\end{array}$ & & \\
\hline$\mu$ & $\begin{array}{c}0.15 \\
(1.88)\end{array}$ & $\begin{array}{c}0.12 \\
(1.86)\end{array}$ & $\begin{array}{c}0.06 \\
(0.57)\end{array}$ & $\begin{array}{c}-0.03 \\
(-0.29)\end{array}$ & \\
\hline Adjusted $R^{2}$ & 0.970 & 0.972 & 0.967 & 0.963 & 0.970 \\
\hline
\end{tabular}




\section{TABLE 4}

\section{Actual and predicted percentage changes of private consumption in 1990-94}

The predicted values are derived from various models and sources, reported in the first column. In the parenthesis below each predicted value we report the corresponding forecast error, i.e. the difference between the predicted value and the actual value.

\begin{tabular}{|c|c|c|c|c|c|}
\hline & 1990 & 1991 & 1992 & 1993 & 1994 \\
\hline \multicolumn{6}{|l|}{$\begin{array}{l}\text { Growth rate of per capite real private } \\
\text { consumption of non-durables and services: }\end{array}$} \\
\hline Actual values & -0.7 & 0.0 & 0.4 & -0.7 & 0.1 \\
\hline $\begin{array}{l}\text { Dynamic forecasts from the model of Table 3, } \\
\text { column 5, estimated for } 1970-89\end{array}$ & $\begin{array}{c}0.2 \\
(+0.9)\end{array}$ & $\begin{array}{c}0.4 \\
(+0.4)\end{array}$ & $\begin{array}{c}0.0 \\
(-0.4)\end{array}$ & $\begin{array}{c}0.8 \\
(+1.5)\end{array}$ & $\begin{array}{c}1.2 \\
(+1.3)\end{array}$ \\
\hline $\begin{array}{c}\text { Dynamic forecasts from an error correction } \\
\text { model, estimated for } 1970-89\end{array}$ & $\begin{array}{c}1.6 \\
(+2.3)\end{array}$ & $\begin{array}{c}1.6 \\
(+1.6)\end{array}$ & $\begin{array}{c}0.3 \\
(-0.1)\end{array}$ & $\begin{array}{c}0.7 \\
(+1.4)\end{array}$ & $\begin{array}{c}1.4 \\
(+1.5)\end{array}$ \\
\hline \multicolumn{6}{|l|}{ Growth rate of total real private consumption: } \\
\hline Actual values & -0.4 & 0.9 & -1.4 & -3.7 & 0.5 \\
\hline $\begin{array}{l}\text { Swedish Ministry of Finance forecast, end of } \\
\text { December } 1990^{1}\end{array}$ & $\begin{array}{c}0.6 \\
(+1.0)\end{array}$ & $\begin{array}{c}1.5 \\
(+0.6)\end{array}$ & $\begin{array}{c}1.9 \\
(+3.3)\end{array}$ & & \\
\hline $\begin{array}{l}\text { Swedish Ministry of Finance forecast, end of } \\
\text { December } 1991^{1}\end{array}$ & & $\begin{array}{c}0.0 \\
(-0.9)\end{array}$ & $\begin{array}{c}1.0 \\
(+2.4)\end{array}$ & $\begin{array}{c}1.2 \\
(+4.9)\end{array}$ & \\
\hline OECD forecast, November $1990^{2}$ & $\begin{array}{c}1.0 \\
(+1.4)\end{array}$ & $\begin{array}{c}1.3 \\
(+0.4)\end{array}$ & & & \\
\hline OECD forecast, May $1992^{2}$ & & & $\begin{array}{c}0.3 \\
(+1.7) \\
\end{array}$ & $\begin{array}{c}0.0 \\
(+3.7)\end{array}$ & \\
\hline
\end{tabular}

${ }^{1}$ Kindly provided by Bharat Barot (National Institute of Economic Research, Stockholm).

2 OECD Economic Surveys - Sweden, 1990/1991 and 1991/1992 issues. 
TABLE 5

\section{Actual and predicted percentage changes of private investment in 1990-94 (differences between actual and predicted changes in parenthesis)}

The predicted values in the second row are derived from the following forecasting model: $I(t)=1.128 I(t-1)+$ $0.493 Y(t-1)-0.678 Y(t-2)+0.338 Y(t-3)-94468.418 R(t-1)$, where $I=$ real gross business investment, $Y=$ real gross domestic product, $R=$ real interest rate, and all the estimated coefficients are significantly different from zero at the 1 percent level. The sources of the forecasts in the other rows are reported in the first column. In the parenthesis below each predicted value we report the corresponding forecast error, i.e. the difference between the predicted value and the actual value.

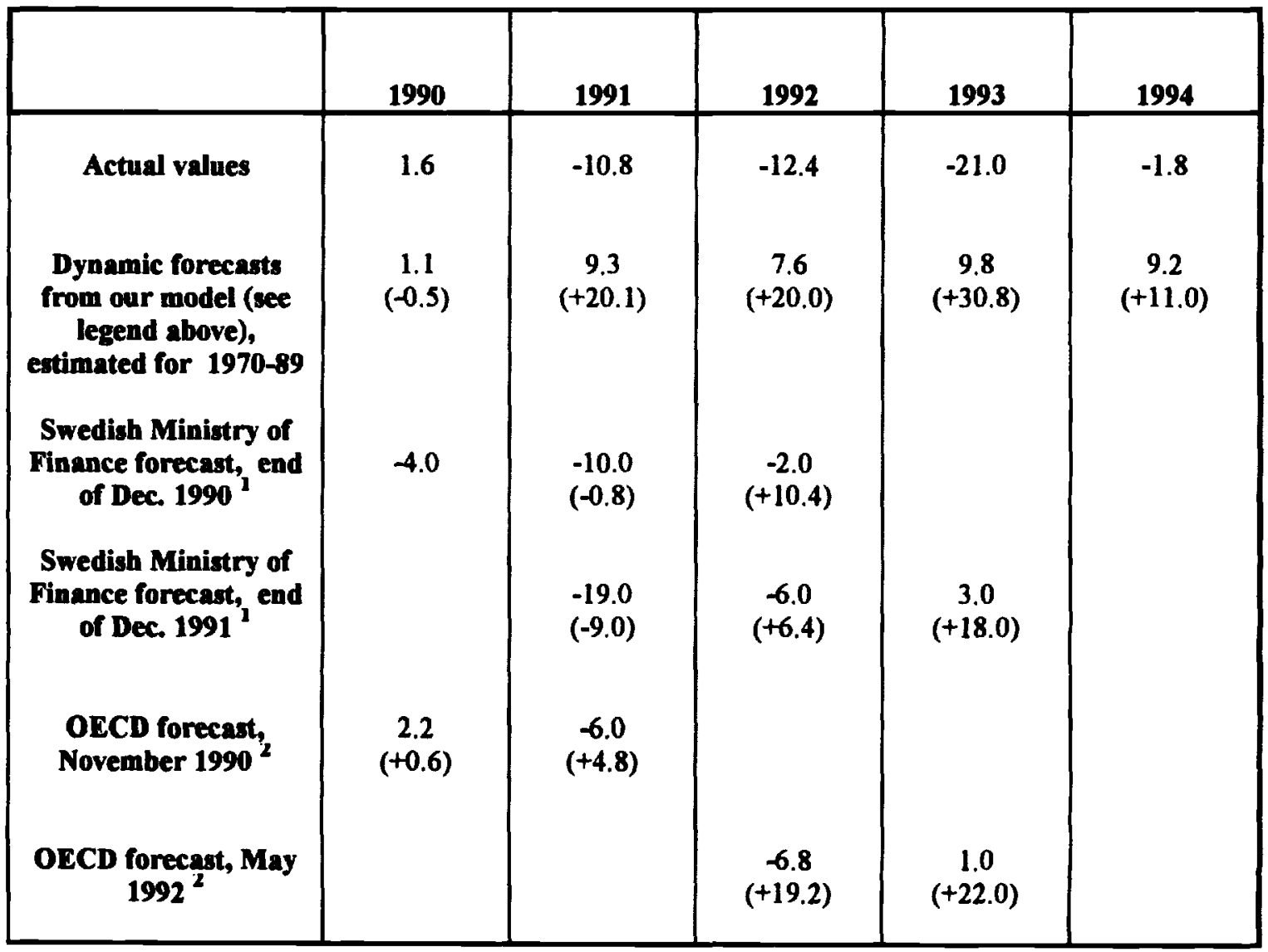

${ }^{1}$ Provided by Bharat Barot (National Institute of Economic Research, Stockholm).

${ }^{2}$ OECD Economic Surveys - Sweden, 1990/1991 and 1991/1992 issues. 


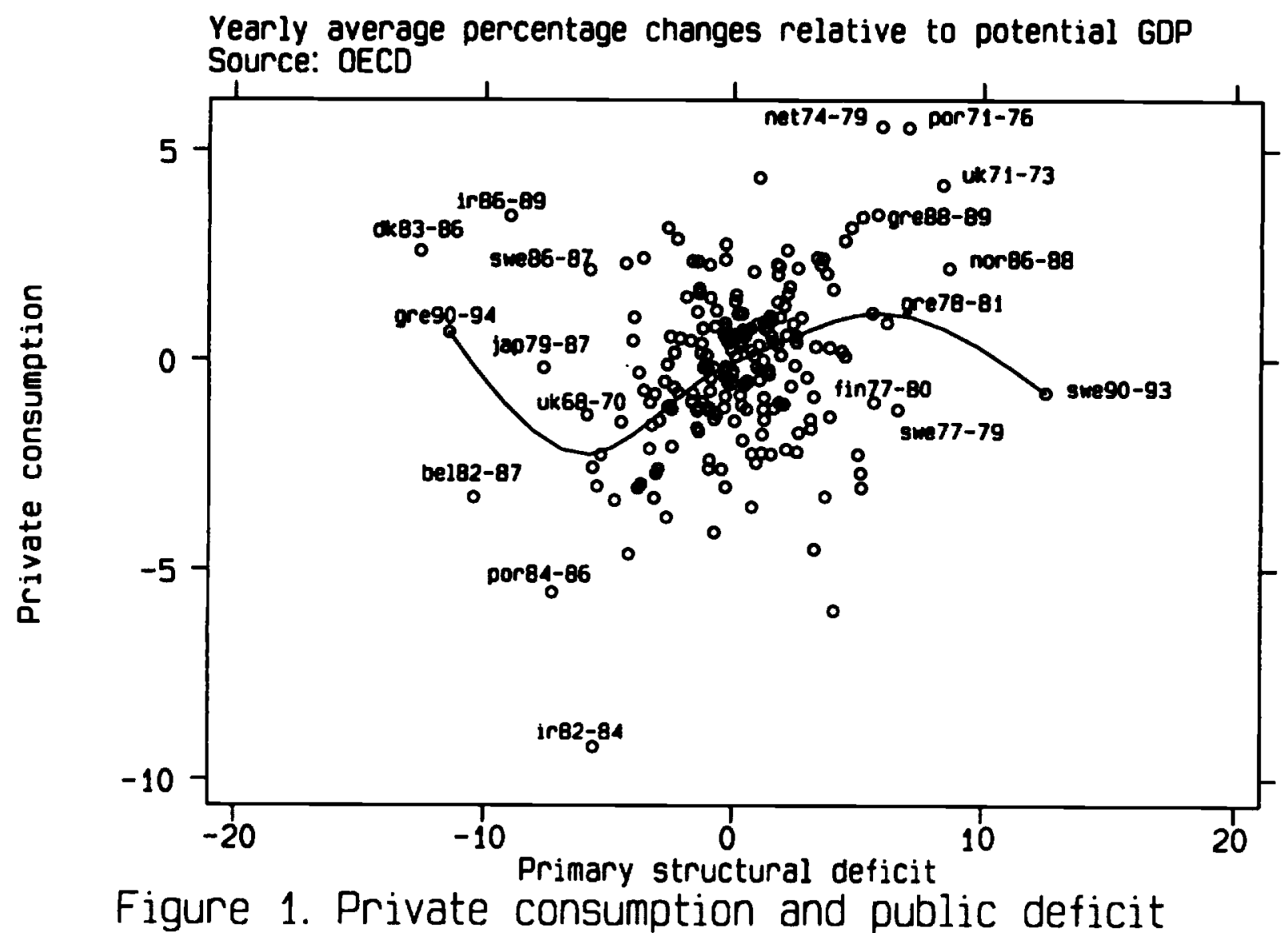


Yearly average percentage changes relative to potential GDP Source: OECD

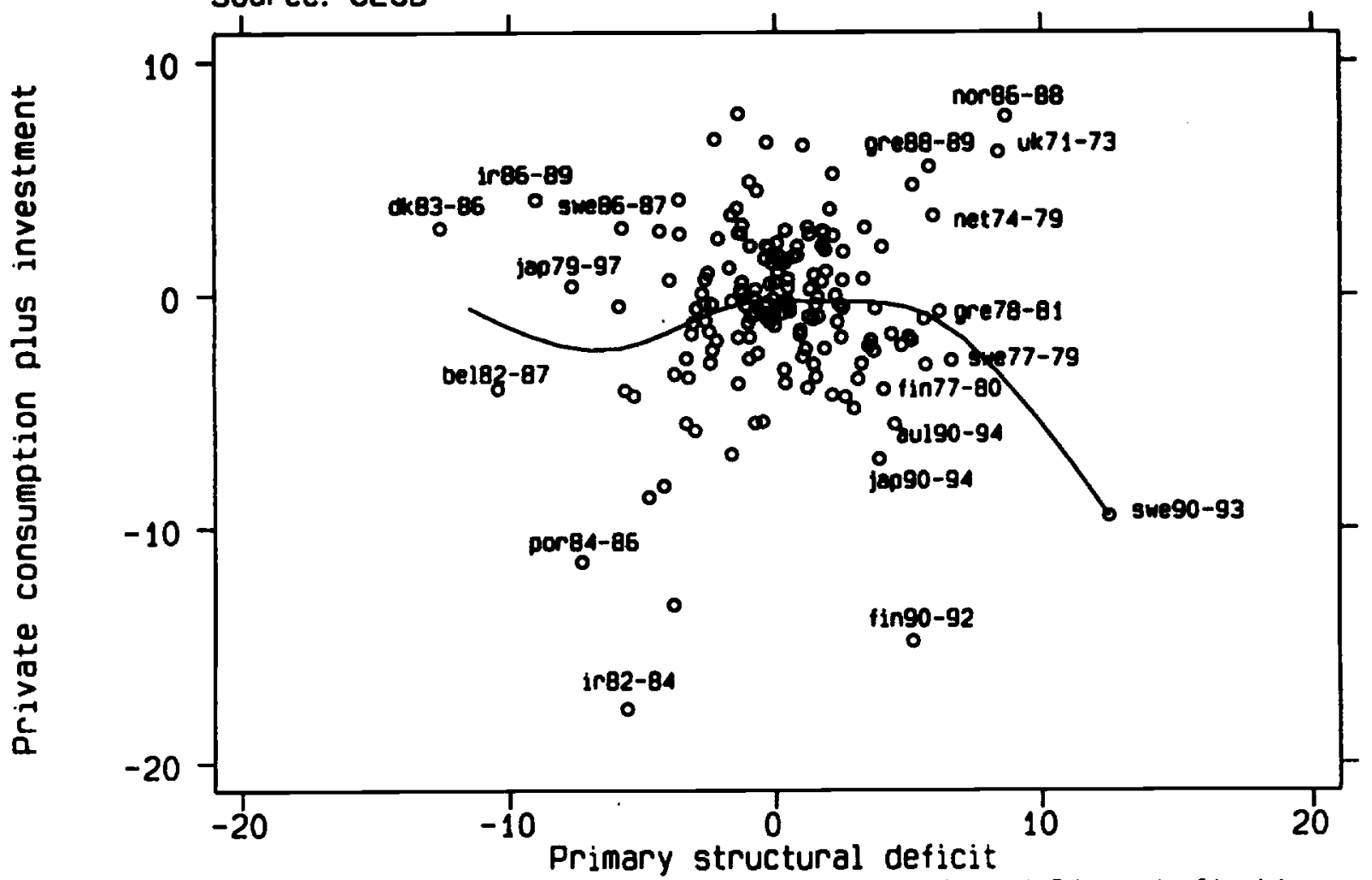

Figure 2. Private domestic demand and public deficit 


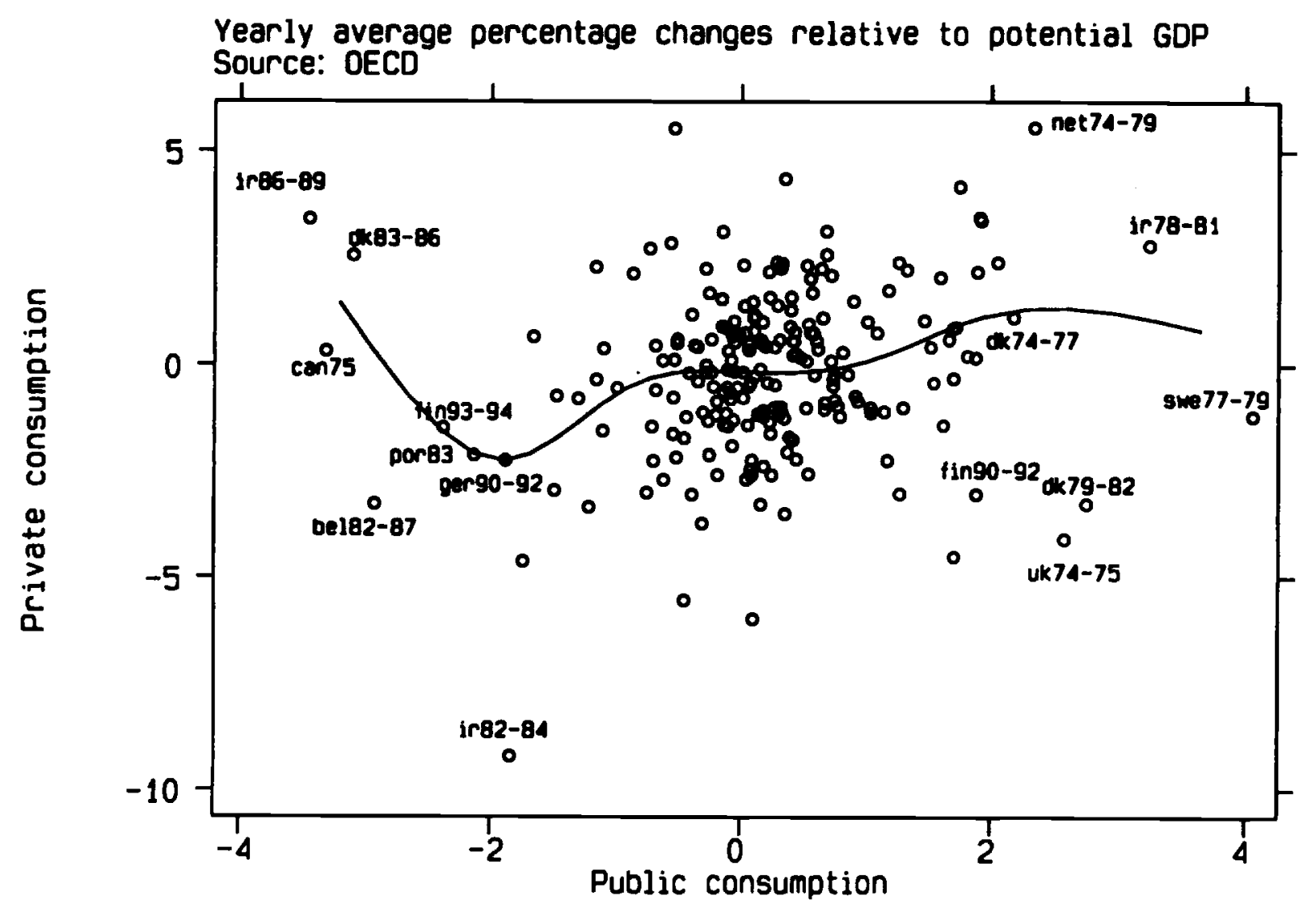

Figure 3. Private consumption and public consumption 


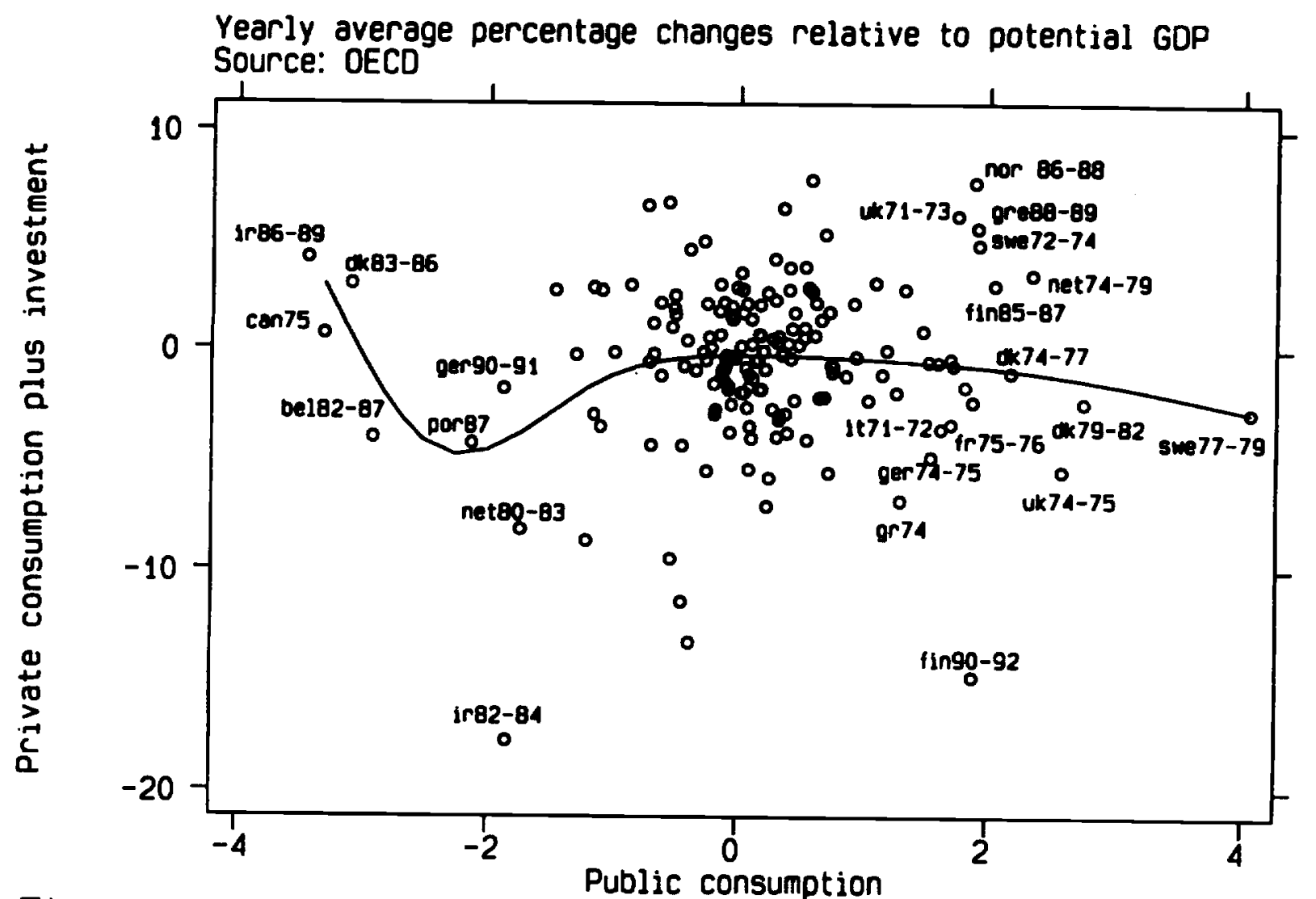

Figure 4. Private domestic demand and public consumption 


\section{Figure 5. Public debt in Sweden}

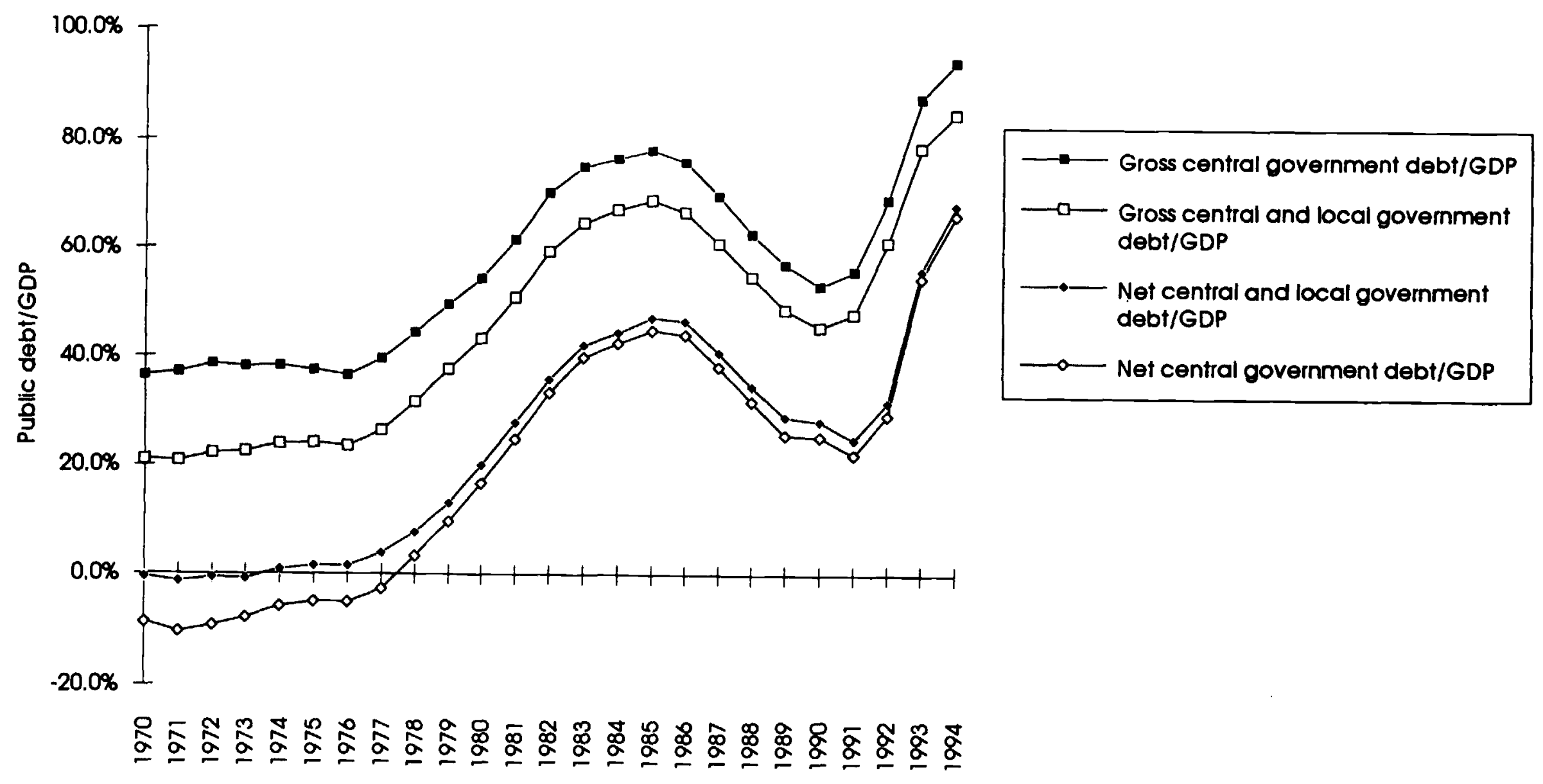


Figure 6. The default risk on Swedish government bonds

Redemption Yields on a 30-year international bond in US dollars issued by the Swedish government (Kingdom of Sweden 1986, 8 5/8 \%, 25/03/2016, darker line) and on a 30-year dollars bond

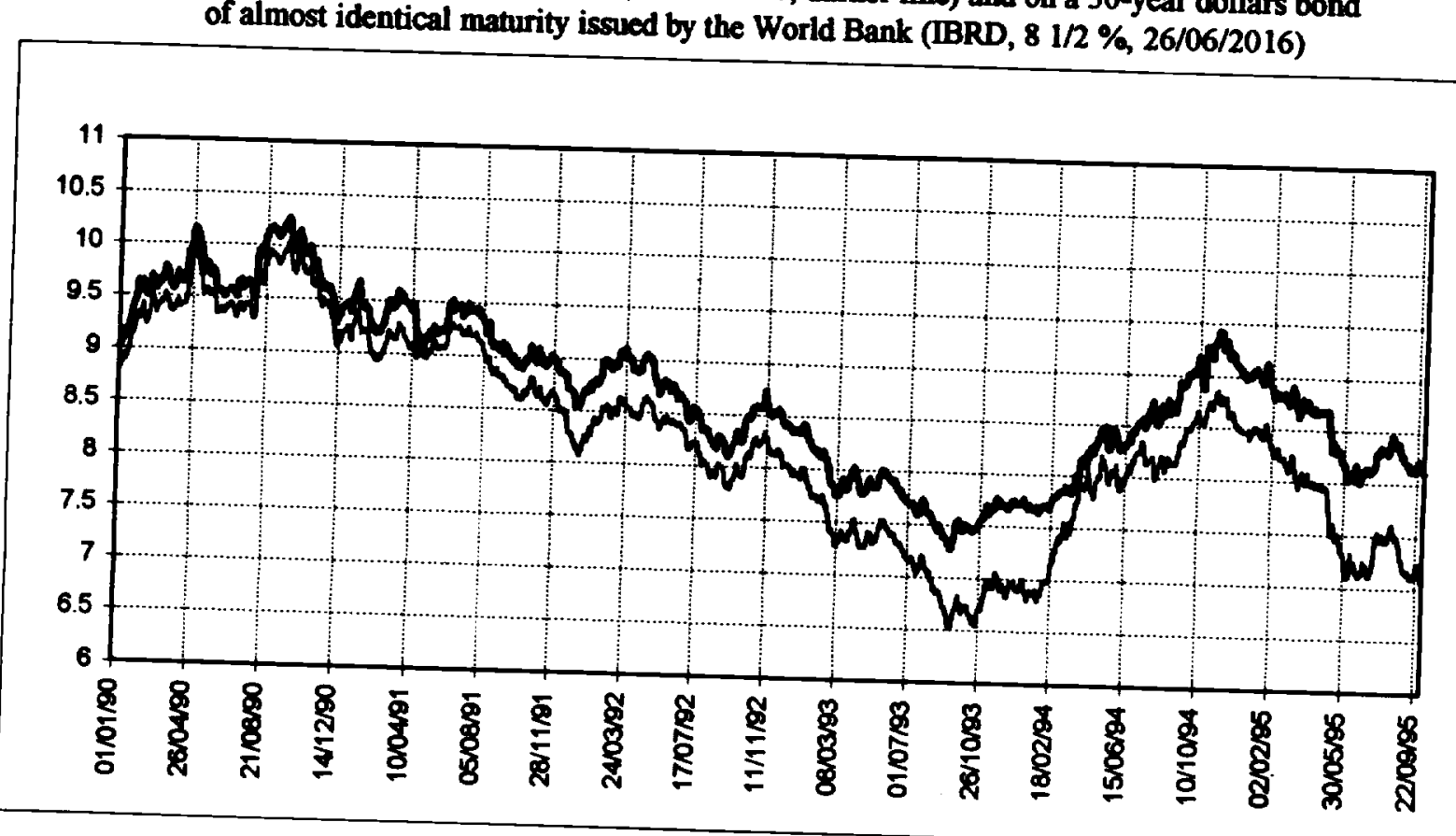

Default risk, defined as the difference between the two yields reported in the top panel

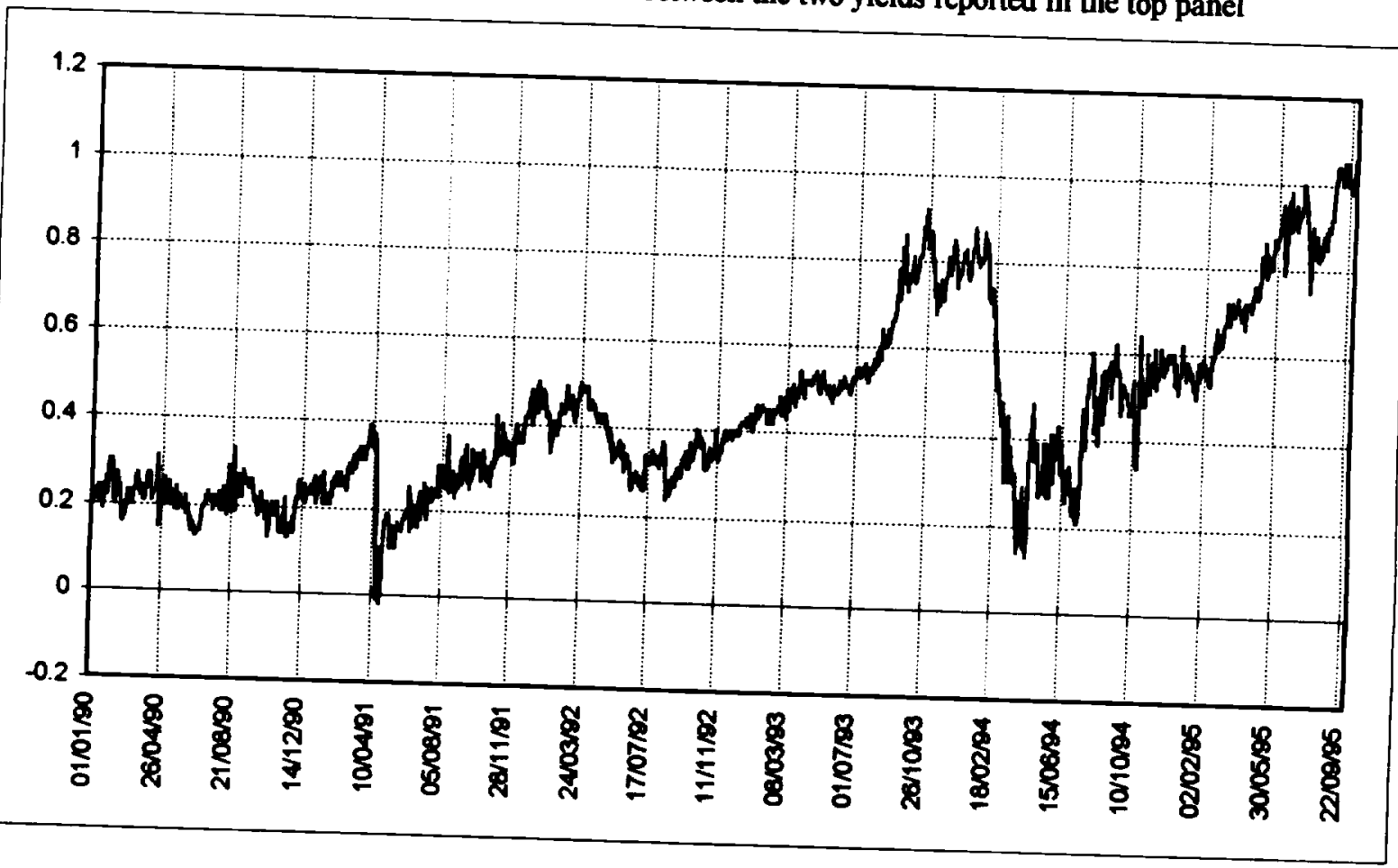


Figure 7. Consumption, investment and public debt in Sweden

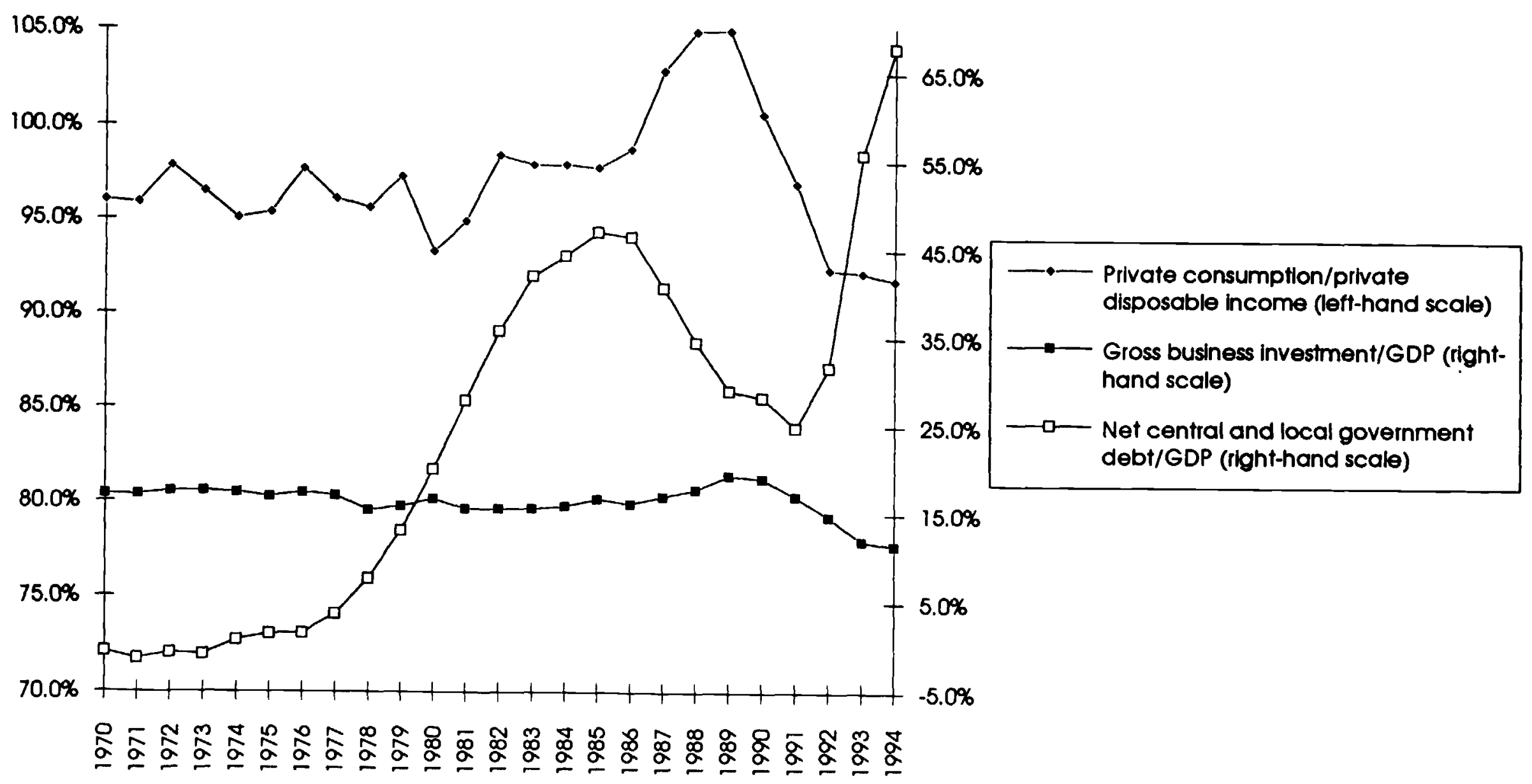


Figure 8. Real asset prices and public debt in Sweden

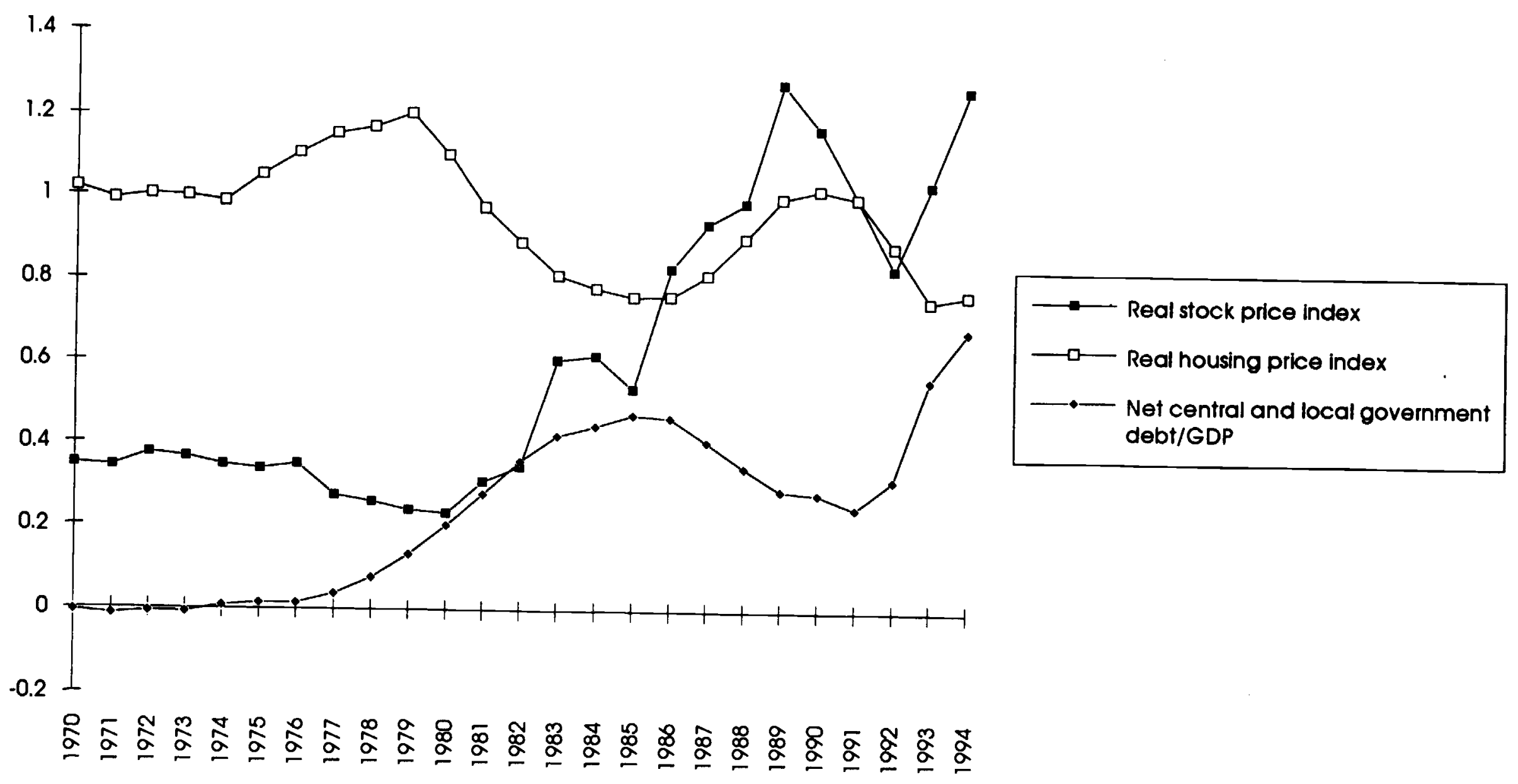




\section{Flgure 9. Real interest rates in Sweden}

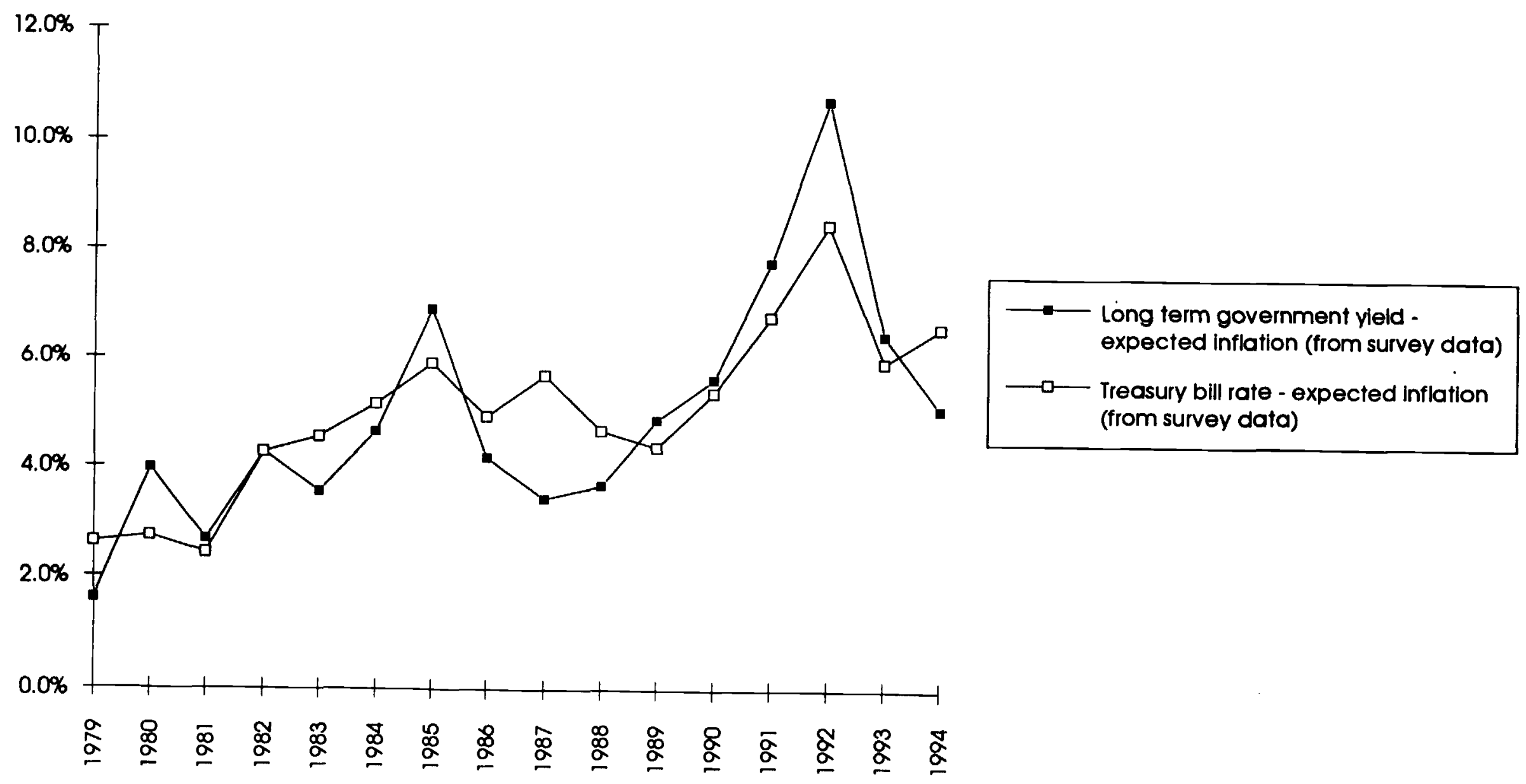

